\title{
Technology proximity between firms and universities and technology transfer
}

\author{
Martin Woerter
}

Published online: 2 February 2011

(C) Springer Science+Business Media, LLC 2011

\begin{abstract}
This paper investigates the technological orientation of firms and universities and their propensity to have knowledge and technology transfer (KTT) activities. This study looks at the technological potential for KTT and how it is used, emphasizing differences between smaller and larger firms. To this end we collected information about the technology activities of firms (patent statistics) and the technology activities of universities. Furthermore, we used survey data on technology transfer activities. We combined the three datasets and found-especially for smaller firms - that great technology proximity fosters transfer activities with different universities (case 1). The same is true if proximity is low and expertise is considerable at universities in the respective technology field (case 2 ). In both cases additional transfer potential exists. In the second case firms engage in transfer activities in order to update and modify their knowledge base and as a consequence improve "competitiveness" in certain technology fields. Furthermore, firms show a tendency to diversify their contacts with universities in order to avoid knowledge lock-in.
\end{abstract}

Keywords Innovation - Knowledge and technology transfer - Technology proximity · Universities · Firms

\section{JEL Classification O30}

\section{Introduction}

With this study we aim at a comprehensive mapping of the technology activities of private firms and the public research sector (i.e., universities) for Switzerland. We want to identify the collaboration potential or knowledge and technology transfer potential between the private and the public research sector. The well-known concepts of "inert areas" (see Leibenstein 1989), "satisficing behavior" (see Simon 1956), "bounded rationality" and "technological competences and knowledge" (see Nelson and Winter 1982), "absorptive

M. Woerter $(\bowtie)$

Swiss Economic Institute (KOF), ETH Zurich, 8092 Zurich, Switzerland

e-mail: woerter@kof.ethz.ch 
capacity" of a firm (see Cohen and Levinthal 1989), the resource based view of a firm (see Penrose 1995; Wernerfelt 1984; Barney 1991) or technology trajectories (see Dosi 1982) are used in the economic literature to describe the ability of a firm to perceive, process and apply external knowledge and/or to change its innovation behavior in order to further develop their technology base and to develop and commercialize new products. We learnt from these concepts that collaboration among actors with similar technology/knowledge bases are more likely than among partners with a very different knowledge background. Thus, technology proximity ${ }^{1}$ matters and it is desirable that private enterprises know about the technology activities at universities and can make use of such activities.

Technology proximity between the two sectors (private and public research) indicates their collaboration potential. It tells us whether they "speak a similar language". With the study at hand we look at the potential for KTT (Knowledge and Technology Transfer) based on "technology proximity" and how it is currently used. ${ }^{2}$ To this end we collected information about the technology activities of firms (patent statistics) and the technology activities of universities (technology fields were assigned; see section on data). Furthermore, we used data on technology transfer activities between the two sectors. We combined the three datasets for the purpose of this study. Section two discusses technology orientation and KTT with universities. In section three we discuss the components of an empirical model and formulate the hypotheses. Section four explains the empirical strategy in order to answer the hypotheses. Section five introduces the different sources of data. Section six shows the results and answers the hypotheses and section seven concludes.

\section{Technological orientation and knowledge and technology transfer with universities}

Technology (knowledge) proximity between firms is an important factor for the probability of collaborations and the likely outcome of a research partnership. Technology proximity is usually measured through the patent activities of firms (see Jaffe 1986; Nooteboom et al. 2007; Cantner and Meder 2007). Although the same argument would be valid for RD (Research and Development) collaborations between firms and universities, this field of research did not get the same attention. Lack of data could be one reason for it. However, technology proximity might play an important role especially for the intensity of transfer contacts with universities. It could be assumed that similar technological orientation of partners facilitates collaboration or even makes a partnership likely. On the other side it is

\footnotetext{
1 Definition technology proximity for the purpose of this paper: Technology proximity between two entities (e.g., university and enterprise) is given, if they are working in the same patent class (technology field). Technology proximity of two entities is not given, if they are working in different patent classes (technology fields). Thus technology proximity has two expressions, i.e. 1 if they work in the same patent class and 0 if they do not work in the same patent class.

2 Technology proximity might be a kind of enabling factor for KTT (Knowledge and Technology Transfer) and thus relevant for transfer policy making. Policy makers should know about technology affinities between the private and public research sector, since it would be rather unwise to "force" collaborations (e.g., through funding schemes) without some knowledge about the technology potential. It would also be unwise to "force" universities into more applied fields of technology just to approximate their research to firm needs. One should be aware of and respect the two different goal setting mechanisms of applied (mostly private) research and basic (mostly public) research and their different purposes from a public point of view (see Hall 2001; Beise et al. 1995 for different goal dimensions). One should also be aware that intensified interactions lead to goal harmonization between the actors; that could be caused by mutual adaptation (see Beise et al. 1995) or through an improved absorptive capacity of private enterprises (see Izushi 2002). As a consequence the characters of universities are changing (see Gibbons et al. 1994).
} 
plausible to assume that more radical type of innovations result from collaboration partners with rather different knowledge bases. The empirical investigations so far are not conclusive in this sense. Nooteboom et al. (2007) state that the relationship between the technology orientation of RD partners and explorative research results in terms of patents follows an inverted U-shape. This means that there exists an "optimal" distance in technology orientation of research partners that is different from having identical knowledge bases and different from having very different knowledge bases. However, Cantner and Meder (2007) do not find an inverted U-shape effect of technology proximity when they are looking at the cooperation propensity. It is indicated that RD partners with very different knowledge bases are unlikely to agree on a partnership at all. Both studies measure technology proximity with patents and do not (to a lesser extent) take into account different dimensions of proximity, like geographical, institutional, and social ones. ${ }^{3}$ Following Boschma (2005) and Boschma and ter Wal (2007) or Breschi and Lissoni (2006) it is likely that the effect of the observed technology proximity is influenced by social or institutional factors. This could mean that, e.g., institutional proximity may compensate the lack of technology proximity in order to agree on a partnership. It is likely that firms are closer in institutional proximity with one another than firms with universities. Hence, firms may have also institutional incentives to collaborate. Institutional differences maybe an obstacle for collaborations between firms and universities. Given those institutional peculiarities it is interesting to look at the importance of technology proximity for knowledge and technology transfer activities between firms and universities.

On an industry level we know that there are sectoral patterns of technology activities (see Pavitt 1984; Verspagen et al. 1994; Schmoch et al. 2003; Broekel 2007) leading to differences in importance of public knowledge for firms' innovative behaviors. Especially for industries with a strong technology base, like the pharmaceutical industry, access to university research became increasingly important (see Powell et al. 1996; in the case of biotechnology).

On a firm level we have got a good understanding about the characteristics of the transfer process but limited knowledge about the importance of technology proximity for the intensity of transfer activities. We know about Switzerland that about $28 \%$ of firms with more than 5 employees have transfer contacts ${ }^{4}$ with universities (see Arvanitis et al. 2007). Large firms and firms in the high-tech sector are significantly more likely to have transfer activities compared to smaller firms and firms in any other sector. Informal, personal contacts and KTT through graduates or the education activities of the universities are the most important forms of KTT in Switzerland (see Arvanitis et al. 2007). Similar studies for other countries and regions also emphasis the importance of human capital and more informal transfer forms (see OECD 2002; Blume and Fromm 2000; Lessmann and Rosner 2004; Salter et al. 2000; Arundel et al. 1995). Furthermore, we know that especially through publications, patent/licenses, and spin-offs university knowledge flows into the entrepreneurial world (see Kaufmann and Tödling 2001; for the importance of transfer

\footnotetext{
${ }^{3}$ For the explanation the different dimensions of proximity see Boschma (2005). Geographical proximity could be of less importance for transfer activities in Switzerland, since Switzerland is a very small country and universities are well distributed across regions. However, we know from investigations in other countries that geographical proximity plays an important role (see Santoro and Gopalakrishnan 2001; for the USA).

4 Broad definition of transfer activities: Knowledge and technology transfer between academic institutions and the business sector is understood in this study as any activities aimed at transferring knowledge or technology that may help either the company or the academic institute-depending on the direction of transfer-to further pursue its activities.
} 
offices). Access to human capital (see Audretsch and Stephan 1996; Stephan 1996) or problem solving capabilities (tacit knowledge), access to new research or development of new products are among the important motivations for transfer activities (see Schartinger 2000; Hall 2004). Important hindering factors are related to "firm deficiencies" (e.g., firm's questions being not interesting for science institutions or lack of interest for scientific projects) but also to "deficiencies on part of the science institutions". Similar results are found for Austria (see Schibany et al. 1999). More concretely, firms observed that it is sometimes difficult to commercialize $R \& D$ results coming from transfer activities and they also noted that to some extent the R\&D orientation of public research institution is not interesting for firms (see Arvanitis et al. 2007). Despite of the mentioned impediments many transfer projects lead to successful market products. It was found that on average innovation and firm performance are positively related (see Arvanitis et al. 2008).

With the study at hand we will combine the knowledge about KTT and the technology proximity between the actors in order to identify unused transfer potentials and improve the knowledge base for policy making. ${ }^{5}$

\section{Empirical model and hypotheses}

Whether a certain type of information or knowledge is important for the innovation activities of a firm depends very often on its knowledge base. Cohen and Levinthal (1989) called the ability to make use of knowledge from other institutions or firms, the absorptive capacity of a firm. The absorptive capacity is quite often approximated through $R \& D$ activities or the skill-level of the employees. We learnt from broad empirical studies that the absorptive capacity (measured by the skill-level of employees or R\&D activities) is an important determinant for KTT activities (see Arvanitis et al. 2007; for Switzerland). Laursen and Salter (2004) investigated for the UK the types of firms that use universities as a source for innovation. They found also that variables related to the absorptive capacity of a firm such as R\&D intensity and long-term R\&D show a positive correlation with KTT activities. However, the absorptive capacity is measured in a very general way (skill-level, $\mathrm{R} \& \mathrm{D}$ activities). In order to choose co-operation partners we need to know more concretely the technology orientation of a firm, since a high skill-level can be found in banks as well as in pharmaceutical companies-nevertheless there is no reason to assume that they have a higher probability to co-operate in $\mathrm{R} \& \mathrm{D}$, since their technology base is too different.

Firms are not anymore the sole actors in their innovation processes (see Malerba 2007). Research co-operations or informal contacts with universities, suppliers, or customers essentially modified the innovation behavior of firms. The partner choice or their perception of what might be an interesting research partner is directed by the technology base of a firm, their working routines, or their quest for new application areas for existing knowledge or technology (see Dosi 1988). The technology proximity between partners is one important driver for collaborations (see Cantner and Meder 2007). Only in rare cases

\footnotetext{
5 In order to capture the technology orientation of firms and universities we refer to the international patent classification (see http://www.wipo.int/classifications/ipc/en/). Patents can be assigned to more than one subclass. Sub-classes are aggregated to more than 100 classes and 8 sections. We assigned technology fields only to firms that filed patent(s). In case of universities we assigned technology fields according to their research activities presented on their websites (see section on data).
} 
firms seek collaborations in order to "radically" change their technology base, like it was the case with the rise of molecular biology (biotechnology) in pharmaceuticals; from an expost point of view the (chemical based) pharmaceutical companies enlarged their knowledge base rather than substituted it. The technology base of a firm is defined as cumulated knowledge, learning, or capabilities from past experiences and in this study it is expressed through patent fields (technology fields). ${ }^{6}$

It is understandable that firms try to continue their work in the same technology field applying similar working routines. It is also an empirical fact that firms try to diversify their external linkages, not only between different types of knowledge partners, e.g., suppliers, customers, and universities, but also within one type of partner (e.g., universities) (see Arvanitis et al. 2007). What might drive such a behavior? Firstly, they can create a greater amount of "incoming spillovers" (see Shapiro and Willig 1990; Greenlee and Cassiman 1999) in order to modify their knowledge base and to update their expertise and to enlarge their research networks. Secondly, such contacts make it easier to recruit graduates or researchers and private $R \& D$ activities increase the probability that highly skilled workers stay in the geographical area (see Sumell et al. 2009). Thirdly, contacts with different university institutes help firms to "escape" from knowledge lock-in. Fourthly, funding schemes force firms to collaborate with (different) universities (that is the case in Switzerland ${ }^{7}$ ).

Against this background we want to test the following four hypotheses in which we distinguish between smaller and larger firms.

\subsection{Hypotheses}

H1 Technology proximity between universities and private enterprises increases the probability of transfer activities and makes it more likely to have more than one university link.

This hypothesis emphasizes the importance of a firm's absorptive capacity (Cohen and Levinthal 1989; Nooteboom et al. 2007; Schmidt 2008). It should be easier for them to assess the relevance of university research in familiar areas. In case that several universities are doing research in those fields, it is likely that firms contact more than one university. This hypothesis emphasizes the exploitative nature of transfer activities rather than their explorative character (see March 1991). To elaborate on this hypothesis we will look at technology fields that are important in both sectors and estimate the probability of transfer activities (see Eq. 1):

\footnotetext{
${ }^{6}$ Since it is the purpose of this study to investigate the meaning of technology knowledge for transfer activities between enterprises and universities, it is important if a firm has knowledge in a certain technology field, independently of the firm's knowledge in other fields. Therefore the absolute number of patent field inscription is used as a proxy for technology knowledge and not the relative number of technology inscriptions.

7 Switzerland's main funding institution for more applied research, CTI (Innovation Promotion Agency), mainly promotes R\&D collaborations between firms and public research institutions. It is inevitable to have a collaboration partner at a public research institution in order to be considered for public support. The rule is that at least $50 \%$ of the total project costs have to be covered by the private partner. The costs on part of the public partner(s) are funded by the CTI in case the project is promoted. Thus, the private partner does not receive any direct financial aid. Promotion of private innovation activities takes place indirectly through funding the public partner in a collaboration project between public and private partners.
} 


$$
\begin{aligned}
\text { intense }_{i}= & \beta_{1} \text { techfield } \_ \text {h }_{i}+\beta_{2} \text { pat }_{i}+\beta_{3} \text { educ }_{i}+\beta_{4} \text { foreign }_{i}+\beta_{5} \text { size }+\beta_{6} \text { dind } 1+\cdots \\
& +\beta_{30} \text { dind } 25+\varepsilon_{i}
\end{aligned}
$$

Intense $_{i}$ measures on the firm-level the number of transfer contacts with different universities (see Table 1), e.g., if a firm has transfer activities with two universities, 'intense' receives the value 2. Techfield_h $h p_{i}$ identifies technology fields (patent classes) that are important for both, the university sector as well as the firm sector, so called "high potentials". 'Important' means that a technology field (patent class) is ranked within the 20 most important technology fields sorted by the number of patent class inscriptions for all firms and all universities respectively. $\mathrm{Pat}_{i}$ controls for the patent activities of firms (0/1). Educ $c_{i}$ controls for the share of tertiarylevel vocational educated employees within a firm. Foreign $n_{i}$ tells us whether a firm is foreign owned (0/1). Size $e_{i}$ measures the number of employees (log of full-time equivalents) and dindl to dind 25 controls (on a two-digit level) for the industry affiliation of a firm (see Table 2). Following $\mathrm{H} 1$ it is assumed that intense $_{i}$ is positively correlated with techfield_hp $p_{i}$ and also positively correlated with our further proxy for the absorptive capacity $e d u c_{i}$. Significant positive signs are also expected for our controls for $\mathrm{pat}_{i}$, foreign $n_{i}$, and $s i z e_{i}$. For the description of the dependent and independent variables see Tables 1 and 2.

H2 There are no transfer activities in technology fields that are not important for both private enterprise, and universities.

This hypothesis addresses the 'possible' case where firms and universities join in order to develop a new technology. "New" means that they do not have research experiences in related technology fields. Collaborations under such conditions are intuitively and empirically (as the results show) very unlikely. However, this hypothesis completes the four possibilities of technology related transfer motivations, i.e., frequent technology activities on both the firm and university side; frequent technology activities on the firm side but not on side of the university; frequent technology activities on the university side but not on the firm side; and infrequent technology activities on both firm and university side.

Following the concept of absorptive capacity and the resource-based view perspective, it is very unlikely to see transfer activities in technology fields where both partners are not experts. Thus, we would assume that technology transfer takes place only occasionally or does not take place in those technology fields at all. In the first case we would expect an insignificant sign of the coefficient and in the latter case a significant negative sign for techfield_l $p_{i}$ is expected (see Eq. 2).

$$
\begin{aligned}
\text { intense }_{i}= & \beta_{1} \text { techfield_lp }_{i}+\beta_{2} \text { pat }_{i}+\beta_{3} \text { educ }_{i}+\beta_{4} \text { foreign }_{i}+\beta_{5} \text { size }+\beta_{6} \text { dind } 1+\cdots \\
& +\beta_{30} \text { dind } 25+\varepsilon_{i}
\end{aligned}
$$

Equation 2 differs from Eq. 1 only in terms of the proxy techfield_l $p_{i}$. Techfield_lp identifies technology fields (patent classes) that are not important for both, the university sector as well as the firm sector, so called "low potentials". 'Not important' means that a technology field (patent class) is ranked within the 20 least important technology fields

Table 1 Dependent variable

Dependent Description
variables

Intense

Number of transfer activities with different universities; no transfer activities equals 0 
Table 2 Independent variables

\begin{tabular}{|c|c|}
\hline Determinants & Description \\
\hline Educ & $\begin{array}{l}\text { Share of employees with tertiary-level vocational education (universities, universities of } \\
\text { applied sciences, other business and technical schools at tertiary level) }\end{array}$ \\
\hline Foreign & Dummy variable; 1 if a firm is foreign owned, 0 if the firms is not foreign owned \\
\hline Pat & Dummy variable; 1 if the firm filed patent(s). 0 if the firm did file patent(s) \\
\hline Size & $\begin{array}{l}\text { The size of firms is measures through the number of employees expressed in full-time } \\
\text { equivalents }(\log )\end{array}$ \\
\hline \multicolumn{2}{|c|}{ Technology fields [see also Appendix (Table 11)] } \\
\hline \multicolumn{2}{|c|}{$\begin{array}{l}\text { Techfield_hp (Technology fields frequently found in private enterprises and in universities (see Figs. 1, 2, 3; } \\
\text { category: high potentials) }\end{array}$} \\
\hline $\mathrm{a} 01$ & $\begin{array}{l}\text { Number of technology field inscriptions in a01 (agriculture, forestry, animal husbandry, } \\
\text { hunting, trapping, fishing) }\end{array}$ \\
\hline $\mathrm{c} 08$ & $\begin{array}{l}\text { Number of technology field inscriptions in c08 (organic macromolecular compounds, their } \\
\text { preparation or chemical working-up, compositions based thereon) }\end{array}$ \\
\hline $\mathrm{c} 12$ & $\begin{array}{l}\text { Number of technology field inscriptions in c12 (biochemistry, beer, spirits, wine, vinegar, } \\
\text { microbiology, enzymology, mutation of genetic engineering) }\end{array}$ \\
\hline g02 & Number of technology field inscriptions in g02 (optics) \\
\hline h04 & Number of technology field inscriptions in h04 (electric communication technique) \\
\hline
\end{tabular}

Techfield_lp (Technology fields not frequently found in private enterprises and in universities (see Figs. 1, 2, 3; category: low potentials)

a46 Number of technology field inscriptions in a46 (brushware)

b06 Number of technology field inscriptions in b06 (generating or transmitting mechanical vibrations in general)

c05 Number of technology field inscriptions in c05 (fertilisers, manufacture thereof)

c13 Number of technology field inscriptions in c13 (sugar industry)

c14 Number of technology field inscriptions in c14 (skins, hides, pelts, leather)

c40 Number of technology field inscriptions in c40 (combinatorial technology)

f17 Number of technology field inscriptions in $\mathrm{f17}$ (storing or distributing gases or liquids)

Techfield_np (Technology fields frequently found at universities and not frequently found in private enterprises (see Figs. 1, 2, 3; category: not used potentials)

a63 Number of technology field inscriptions in a63 (sports, games, amusements)

g02 Number of technology field inscriptions in g02 (optics)

g11 Number of technology field inscriptions in g11 (information storage)

h05 Number of technology field inscriptions in h05 (electric techniques not otherwise provided for)

Techfield_ls (Technology fields frequently found in private enterprises and not frequently found in universities (see Figs. 1, 2, 3; category: lone stars)

b65 Number of technology field inscriptions in b65 (conveying, packing, storing, handling thin or filamentary material)

Control variables

Dind1 to dind25 25 industry dummies (two-digit)

Instruments in order identify the 0/1 decision to have transfer activities

Info Obstacle: difficulties to get information about the research activities at universities. Firms assessed the importance of this obstacle based on a five-point Likert scale (1 not important ... 5 very important)

Quest Obstacle: our research and development questions are not interesting for universities (from a firm point of view). Firms assessed the importance of this obstacle based on a five-point Likert scale (1 not important ... 5 very important) 
Table 3 Composition of the data set-number of observations according to industries

\begin{tabular}{|c|c|c|c|c|c|c|c|c|c|}
\hline \multirow[t]{2}{*}{ Industries } & \multirow[t]{2}{*}{$\begin{array}{l}\text { Obs. } \\
\text { survey } \\
(\text { KOF) }\end{array}$} & \multirow[t]{2}{*}{$\begin{array}{l}\text { No. of } \\
\text { transfer } \\
\text { firms (KOF) }\end{array}$} & \multicolumn{4}{|c|}{$\begin{array}{l}\text { Number of transfer } \\
\text { contacts with } \\
\text { universities (KOF) }\end{array}$} & \multirow[t]{2}{*}{$\begin{array}{l}\text { R\&D active } \\
\text { firms } \\
\text { (NetBreeze) }\end{array}$} & \multirow[t]{2}{*}{$\begin{array}{l}\text { No. of } \\
\text { patents } \\
\text { (NetBreeze) }\end{array}$} & \multirow{2}{*}{$\begin{array}{l}\text { No. of } \\
\text { patent field } \\
\text { inscriptions } \\
\text { (NetBreeze) }\end{array}$} \\
\hline & & & 1 & 2 & 3 & $4+$ & & & \\
\hline Food/beverage & 127 & 34 & 7 & 11 & 8 & 7 & 48 & 1,219 & 2,372 \\
\hline Textile & 30 & 9 & 2 & 2 & 2 & 3 & 19 & 247 & 417 \\
\hline Clothing/leather & 11 & 0 & 3 & 3 & 2 & 3 & 0 & 37 & 55 \\
\hline Wood processing & 56 & 9 & 6 & 1 & 2 & 1 & 12 & 45 & 98 \\
\hline Paper & 31 & 9 & 8 & 5 & 2 & 4 & 28 & 175 & 336 \\
\hline Publishing & 91 & 17 & 2 & 10 & 4 & 14 & 20 & 278 & 488 \\
\hline Chemicals & 93 & 37 & 3 & 2 & 3 & 5 & 106 & 4,683 & 11,448 \\
\hline Plastics/rubber & 58 & 13 & 2 & 2 & 3 & 4 & 50 & 581 & 1,105 \\
\hline $\begin{array}{l}\text { Other non metallic mineral } \\
\text { products }\end{array}$ & 47 & 13 & 4 & 2 & 1 & 3 & 29 & 276 & 510 \\
\hline Metal & 39 & 9 & 18 & 6 & 10 & 11 & 21 & 345 & 788 \\
\hline Metalworking & 173 & 37 & 6 & 23 & 23 & 38 & 98 & 1,769 & 3,397 \\
\hline Machinery & 269 & 116 & 14 & 5 & 10 & 11 & 240 & 7,767 & 15,034 \\
\hline $\begin{array}{l}\text { Electrical } \\
\text { machinery }\end{array}$ & 87 & 33 & 1 & 9 & 10 & 26 & 64 & 2,421 & 4,780 \\
\hline $\begin{array}{l}\text { Electronic/ } \\
\text { instruments }\end{array}$ & 152 & 67 & 3 & 1 & 1 & 4 & 144 & 4,522 & 8,857 \\
\hline Watches & 54 & 6 & 2 & 3 & 2 & 4 & 46 & 900 & 1,618 \\
\hline Vehicles & 29 & 9 & 7 & 0 & 5 & 3 & 24 & 550 & 1,151 \\
\hline $\begin{array}{l}\text { Other } \\
\text { manufacturing }\end{array}$ & 54 & 12 & 14 & 2 & 9 & 6 & 40 & 1,075 & 2,115 \\
\hline Energy/water & 49 & 15 & 4 & 5 & 6 & 6 & 0 & 40 & 65 \\
\hline Construction & 271 & 32 & 4 & 8 & 1 & 6 & 58 & 815 & 1,554 \\
\hline Wholesale & 215 & 35 & 3 & 9 & 6 & 5 & 109 & 2,726 & 5,485 \\
\hline Transport & 154 & 21 & 13 & 7 & 5 & 14 & 32 & 565 & 911 \\
\hline Banking/insurance & 179 & 35 & 2 & 6 & 11 & 11 & 68 & 968 & 1,704 \\
\hline Computer services & 79 & 28 & 7 & 12 & 1 & 23 & 40 & 671 & 1,347 \\
\hline Business services & 216 & 67 & 2 & 11 & 8 & 2 & 74 & 1,166 & 2,527 \\
\hline Telecommunication & 18 & 6 & 3 & 2 & 2 & 7 & 10 & 207 & 371 \\
\hline Total & 2,582 & 669 & 128 & 138 & 127 & 214 & 1,388 & 34,048 & 68,533 \\
\hline
\end{tabular}

Base Swiss Innovation Panel (SIP) with 5,693 firms. KOF Survey 2,582 answers (response rate 45\%); NetBreeze Survey (based on SIP) 1,388 R\&D active firms and 920 firms with patent activities. 62 firms do not tell us the cooperation partner(s) or do not have transfer activities with national universities. No. of patents and patent field inscriptions between 1904 and May 2008

sorted by the number of patent class inscriptions for all firms and all universities respectively.

H3 Firms do not have transfer activities with universities in technology fields that are frequently researched by private enterprises and not frequently researched at universities.

It is very unlikely that firms have transfer activities with universities in technology fields that are unimportant in the academic world and thus not well researched at universities (see Eq. 3). As a consequence we do not expect significant transfer results in those technology fields (techfield_ls $s_{i}$. 
Table 4 Technological fields of universities/science institutions

\begin{tabular}{|c|c|c|c|c|c|c|c|c|c|c|}
\hline \multirow[t]{2}{*}{ Institution } & \multirow{2}{*}{$\begin{array}{l}\text { Websites } \\
\text { searched }\end{array}$} & \multirow[t]{2}{*}{ Hits } & \multicolumn{8}{|c|}{ Technology fields (sections) } \\
\hline & & & A & B & $\mathrm{C}$ & $\mathrm{D}$ & $\mathrm{E}$ & $\mathrm{F}$ & G & $\mathrm{H}$ \\
\hline $\begin{array}{l}\text { University of Applied } \\
\text { Sciences Bern }\end{array}$ & 737 & 537 & 12 & 85 & 8 & 1 & 12 & 3 & 199 & 217 \\
\hline $\begin{array}{l}\text { Engineering School of } \\
\text { Changins }\end{array}$ & 103 & 56 & 5 & 10 & 7 & 0 & 4 & 5 & 19 & 6 \\
\hline $\begin{array}{c}\text { Swiss Federal Institute of } \\
\text { Technology Lausanne }\end{array}$ & 15,811 & 9,940 & 853 & 942 & 1,357 & 98 & 571 & 404 & 2,908 & 2,807 \\
\hline $\begin{array}{l}\text { Swiss Federal Institute of } \\
\text { Technology Zurich }\end{array}$ & 22,699 & 14,143 & 836 & 767 & 922 & 95 & 334 & 554 & 8,363 & 2,272 \\
\hline $\begin{array}{l}\text { Swiss Federal Institute of } \\
\text { Aquatic Science and } \\
\text { Technology }\end{array}$ & 253 & 168 & 18 & 18 & 30 & 7 & 33 & 3 & 44 & 15 \\
\hline $\begin{array}{l}\text { Swiss Federal Institute for } \\
\text { Forest, Snow and } \\
\text { Landscape Research }\end{array}$ & 271 & 168 & 26 & 9 & 45 & 0 & 25 & 0 & 53 & 10 \\
\hline $\begin{array}{l}\text { University of Applied } \\
\text { Sciences Northwestern } \\
\text { Switzerland }\end{array}$ & 28 & 15 & 2 & 2 & 2 & 1 & 2 & 0 & 3 & 3 \\
\hline $\begin{array}{l}\text { University of Applied } \\
\text { Sciences western } \\
\text { Switzerland }\end{array}$ & 275 & 166 & 16 & 0 & 0 & 0 & 2 & 2 & 133 & 13 \\
\hline $\begin{array}{l}\text { Interstate University of } \\
\text { Applied Sciences of } \\
\text { Technology Buchs }\end{array}$ & 22 & 12 & 0 & 0 & 0 & 0 & 0 & 0 & 8 & 4 \\
\hline $\begin{array}{l}\text { University of Applied } \\
\text { Sciences Rapperswil }\end{array}$ & 648 & 431 & 21 & 42 & 25 & 14 & 48 & 12 & 131 & 138 \\
\hline $\begin{array}{l}\text { College of Technology } \\
\text { Zurich }\end{array}$ & 249 & 129 & 3 & 7 & 7 & 1 & 14 & 1 & 80 & 16 \\
\hline $\begin{array}{l}\text { University of Applied } \\
\text { Sciences of Southern } \\
\text { Switzerland }\end{array}$ & 309 & 279 & 25 & 62 & 20 & 5 & 22 & 26 & 32 & 87 \\
\hline University of Lugano & 555 & 291 & 41 & 10 & 16 & 4 & 9 & 42 & 107 & 62 \\
\hline University of Basel & 2,589 & 1,571 & 376 & 169 & 225 & 50 & 52 & 39 & 447 & 213 \\
\hline University of Bern & 7,853 & 5,318 & 1,492 & 441 & 535 & 73 & 440 & 158 & 1,216 & 963 \\
\hline University of St. Gallen & 17 & 5 & 3 & 0 & 0 & 0 & 0 & 0 & 2 & 0 \\
\hline University of Zurich & 8,969 & 6,199 & 1,097 & 713 & 1,160 & 161 & 418 & 270 & 1,485 & 895 \\
\hline University of Fribourg & 127 & 80 & 4 & 14 & 20 & 0 & 3 & 0 & 5 & 34 \\
\hline University of Lausanne & 247 & 115 & 9 & 5 & 7 & 0 & 19 & 3 & 52 & 20 \\
\hline University of Neuchatel & 2 & 2 & 0 & 0 & 2 & 0 & 0 & 0 & 0 & 0 \\
\hline $\begin{array}{l}\text { Zurich University of Applied } \\
\text { Sciences Winterthur }\end{array}$ & 978 & 568 & 41 & 63 & 73 & 8 & 50 & 16 & 190 & 127 \\
\hline Total & 62,742 & 40,193 & 4,880 & 3,359 & 4,461 & 518 & 2,058 & 1,538 & 15,477 & 7,902 \\
\hline
\end{tabular}

"Hits" shows us the number of websites related to technological fields found on the servers of the respective university/science institution. We only searched servers related to science institutes (economics, humanities, or law have been excluded). Technological fields (see http://depatisnet.dpma.de/ipc/ipc.do): A (human necessities), B (performing operations, transporting), C (chemistry, metallurgy), D (textiles, paper), E (fixed constructions), F (mechanical engineering, lighting, heating, weapons, blasting), $\mathrm{G}$ (physics), and $\mathrm{H}$ (electricity). A to $\mathrm{H}$-technological assignments for the respective technology field 


$$
\begin{aligned}
\text { intense }_{i}= & \beta_{1} \text { techfield_ls }_{i}+\beta_{2} \text { pat }_{i}+\beta_{3} \text { educ }_{i}+\beta_{4} \text { foreign }_{i}+\beta_{5} \text { size }+\beta_{6} \text { dind } 1+\cdots \\
& +\beta_{30} \text { dind } 25+\varepsilon_{i}
\end{aligned}
$$

Equation 3 differs from Eq. 2 only in terms of the proxy for techfield_ls $s_{i}$. Techfield_ll $s_{i}$ identifies technology fields (patent classes) that are important for the firm sector and not important for the university sector, so called "lone stars". "Not important' for the university sector means that a technology field is ranked within the 20 least important technology fields sorted by the number of "hits" 8 for technology fields (see also section on data issues). 'Important' for the firm sector means that a technology field (patent class) is ranked within the 20 most important technology fields sorted by the number of patent class inscriptions.

H4 Firms do have transfer relations with different partners' from universities in spite of technological differences, if they want to essentially modify or change their technology orientation.

With this hypothesis we emphasize a more resource (capability)-based view of a firm (see Penrose 1995; Wernerfelt 1984; Barney 1991; Barney et al. 2001) and the more explorative nature of transfer collaborations from the firm's point of view (see March 1991). From a resource-based perspective firms are heterogeneous as to their resource endowments and capabilities. Thus, the resource endowment is firm-specific and relatively difficult to transfer or to modify. Teece et al. (1997) mention several reasons for the persistence of firm behavior due to the specificity of resource endowment: firms lack the organizational capacity to develop new competences, some assets are not tradable (e.g., tacit knowledge), and needed inputs have to be bought at relatively high prices that reduce possible rents. In this context, the "sticky" character of the resource endowment makes it difficult to change the knowledge base of a firm even when market conditions urge them to do so. Strategies are necessary to change or modify the resource endowment and thus improve firms' performance (see Wernerfelt 1984; Kor and Mahoney 2004). KTT with universities is one feasible way to modify the knowledge base of firms within their technology path. This is confirmed by firms' assessments of the main motives for KTT activities with universities. Firms are motivated, firstly, to get better access to human capital (see Geisler and Rubinstein 1989; Schartinger et al. 2001; Onida and Malerba 1989). Secondly, to have better access to knowledge and technology for improving the firm's knowledge base (see Lee 2000; Santoro and Chakrabarti 2002; Schmoch 2003; Arvanitis et al. 2007). Thirdly, KTT is used to build up new fields of research (see Onida and Malerba 1989; Lee 2000). To work on this hypothesis we look at technology fields that are frequently researched at universities and not frequently researched in private enterprises. It is assumed that firms with such a type of transfer situation want to modify or change their knowledge base. Those firms are likely to be found in markets with intensive R\&D related competition, e.g., high-tech industries. Thus we would expect a positive correlation between number of transfer activities and such technology fields (see Eq. 4). A negative correlation would be against this hypothesis.

\footnotetext{
8 "hits" shows us the number of websites related to technology fields found on the servers of the respective university/science institution. We only searched servers related to science institutes (economics, humanities, or law have been excluded).
} 


$$
\begin{aligned}
\text { intense }_{\mathrm{i}}= & \beta_{1} \text { techfield_np }_{i}+\beta_{2} \text { pat }_{i}+\beta_{3} \text { educ }_{i}+\beta_{4} \text { foreign }_{i}+\beta_{5} \text { size }+\beta_{6} \text { dind } 1+\cdots \\
& +\beta_{30} \text { dind } 25+\varepsilon_{i}
\end{aligned}
$$

Equation 4 differs from Eq. 3 only in terms of the proxy for techfield_np ${ }_{i}$. Techfield_np $i$ identifies technology fields (patent classes) that are not important for the firm sector but important for the university sector, so called "not used potentials". 'Not important' for the firm sector means that a technology field is ranked within the 20 least important technology fields sorted by the number of patent field inscriptions. 'Important' for the university sector means that a technology field (patent class) is ranked within the 20 most important technology fields for universities.

\subsection{Endogeneity}

Since it is possible that the technology profile of a firm is determined by its past transfer activities, there is a potential endogeneity of the technology fields and the intensity of knowledge transfer. However, following Dosi $(1982,1988)$ we see that firms follow a technology trajectory and external knowledge is only considered if it lies within this technology path. Innovation is an incremental path dependent process. Therefore it is unlikely that the number of transfer contacts with universities radically change the existing knowledge base of firms. Furthermore Cantner and Meder (2007) found that past collaboration experiences do not increase the probability of collaborations with different research partners. This indicates that past collaboration activities did not lead to a radical change in the knowledge base, in such a way that it had caused collaboration contacts with other partners. Thus it is plausible to assume that the knowledge base of a firm changes in a more sluggish way than the number of university contacts (our dependent variable) and endogeneity is not an issue. ${ }^{9}$

\section{Empirical strategy}

In the following we describe the necessary (preparative) steps and estimation procedures in order to estimate our Eqs. 1, 2, 3 and 4 (see above).

(a) Firm side: we sorted the technological fields (class level) according to the number of firms' patent field inscriptions.

(b) University side: we sorted the technology fields (class level) according to the number of technology fields assigned to universities (hits).

(c) We compared the 20 most important (frequently researched) technology fields on the part of private enterprises with the 20 most important technology fields on the part of the university sector and looked for similarities and dissimilarities. In the same way we investigated the 20 least important technology fields in both the sectors public universities and private enterprises. ${ }^{10}$

\footnotetext{
${ }^{9}$ For a similar reasoning in terms of technology adoption and organizational change see Battisti et al. (2007) or Bresnahan et al. (2002), Hollenstein (2004), Hempell et al. (2004). We can not test endogeneity econometrically due to data limitations. We would need at least 104 valid instruments for the technology fields identified (see Wooldridge 2003; for valid instruments).

${ }^{10}$ We also looked at the 10 and 30 most (least) important technology fields. The results are showing the following trend: Looking at a smaller group (e.g., the 10 most (least) important fields) makes the results
} 
(d) As a result we could identify four quadrants (see Figs. 1, 2, 3), i.e.,:

- 'high potentials': technology fields frequently found in private enterprises and at universities;

- 'low potentials': technology fields not frequently found in private enterprises and at universities;

- 'not used potentials': technology fields frequently found at universities and not frequently found in private enterprises;

- 'lone stars': technology fields frequently found in private enterprises and not frequently found at universities;

(e) High potentials, low potentials, not used potentials, and lone stars could be identified for three different size-related groups of private enterprises, i.e., all firms, firms with less than 500 employees, and for firms with less than 300 employees. ${ }^{11}$

(f) We estimated our Eqs. (1, 2, 3, 4; see above) in order to identify if the technological orientation of a firm has an impact on the propensity and intensity (diversification) of transfer activities with universities. ${ }^{12}$ The number of transfer contacts with different universities/research institutions is the dependent variable (see Table 1). In case a firm does not have transfer activities we assigned a zero. This means that we inflated zeros which suggests a zero inflated estimator for count data. Using STATA software we applied the "zinb" (zero inflated negative binomial) procedure with heteroscedasticity robust standard errors. All estimations passed the "voung test" for the zero inflated negative binomial estimators. The first stage was estimated with two instruments, i.e., "quest" and "info" (see list of independent variables; Table 2). "Quest" (difficulties to get information about research activities at universities) and "info" (firms' R\&D questions are not interesting for universities) are chosen, since they are significant impediments for technology transfer activities with universities. Firms confronted with such obstacles are unlikely to have transfer activities at all and as a consequence we would not observe the number of linkages for those firms. ${ }^{13}$

Footnote 10 continued

clearer. For instance we would find only positive significant signs in the field of high potentials. Looking at a greater group (e.g., the 30 most (least) important fields) makes the results less clearer. For instance, some technology fields found in 'not used potentials' or 'lone stars' are now found in the category 'high potentials'. Basically we see that the larger the group, the more heterogeneous are the results and the smaller the group the more homogeneous are the results. After some trials it turned out that 20 fields is the largest possible group in order to get rather homogenous results.

11 With the different size groups we mainly want to distinguish between small and large firms. Firms with more than 500 employees are seen as large firms in Switzerland. The group of firms with less than 300 employees can be seen as a kind of sensitivity test of the '500 employees' frontier. Sample size does not permit an investigation of much smaller size groups.

12 Technology orientation of a firm is measured in absolute terms. I also calculated a relative measure (number of technology field inscriptions in a certain technology field related to all field inscriptions of a firm), indicating a type of technology specialization. Some preliminary estimations with the relative measure shows similar patterns, e.g. 'high potentials' with positive signs, 'low potentials' with negative signs etc. However, technology fields with significant signs are different. That is not surprising, since this way we look whether firms specialized in a technology field are more likely to have transfer contacts with different universities. We see, for instance, that competences in b23 are not sufficient to have transfer contacts; but if a firm is specialized in b23, transfer activities with different universities are very likely.

${ }^{13}$ For a similar reasoning of choosing instruments in a zero-inflated negative binomial estimation see Kahn (2005, p. 276). 


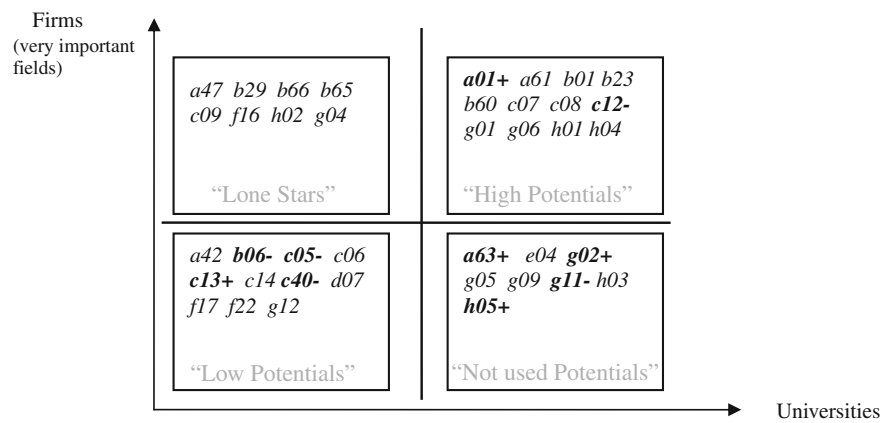

(very important fields)

Fig. 1 Technological fields and the probability to have technology transfer. All firms. Note High potentials-upper right corner (technological fields frequently found in private enterprises and in universities). Low potentials-lower left corner (technological fields not frequently found in both private enterprises and universities). Not used potentials-lower right corner (frequently found at universities and not frequently found in private enterprises). Lone stars-upper left corner (frequently found in private enterprises and not frequently found at universities). Frequency refers to the 20 most important (according to counts in the respective technological field) or 20 least important technological fields. 'a47', 'b29', 'a01', etc. symbolize the technological field (see Table 11 in the Appendix for the description). Highlighted symbols identify technology fields with significant relations to the intensity of transfer activities. \pm indicates if the direction of the observed relationship

In addition to the number of patent field inscriptions on a class level we controlled for patent activities (pat) of firms. Furthermore we control for the education level of the employees (educ), foreign ownership (foreign), firm size (size), and sector affiliation of the firm [25 industry dummies (two-digit)].

(g) We added the information of significant technology fields to our quadrants by highlighting the respective technological classification (see Figs. 1, 2, 3).

\section{Data}

For this study we used three data sources. Firstly, and in co-operation with NetBreeze, ${ }^{14}$ we assigned technology fields to R\&D active Swiss firms and Swiss universities based on patent statistics (class level). ${ }^{15}$

On the firm side, we used the information on "esp@cenet (patent application and granted patents around the world-www.espacenet.com). We assigned technology fields according to the patent classification ${ }^{16}$ (class level) to single firms. Thus we only assigned technology fields to firms with patent activities ( 920 firms). R\&D active firms without patent activities or non $R \& D$ active firms had no technological assignment. We did not assign the patent fields manually; instead we used a software program developed by

\footnotetext{
${ }_{14}$ NetBreeze is an ETH spin-off that developed an internet search engine (http://www.netbreeze.ch).

15 Patents are not a perfect indicator (see Griliches 1990). However, most of the criticism refers to patents as an innovation output measure or as an economic indicator. In the study at hand we use the patent statistic as an indicator for the knowledge base of a firm. Thus most of the criticism does not apply.

${ }^{16}$ For the patent classification please refer to http://depatisnet.dpma.de/ipc/ipc.do.
} 


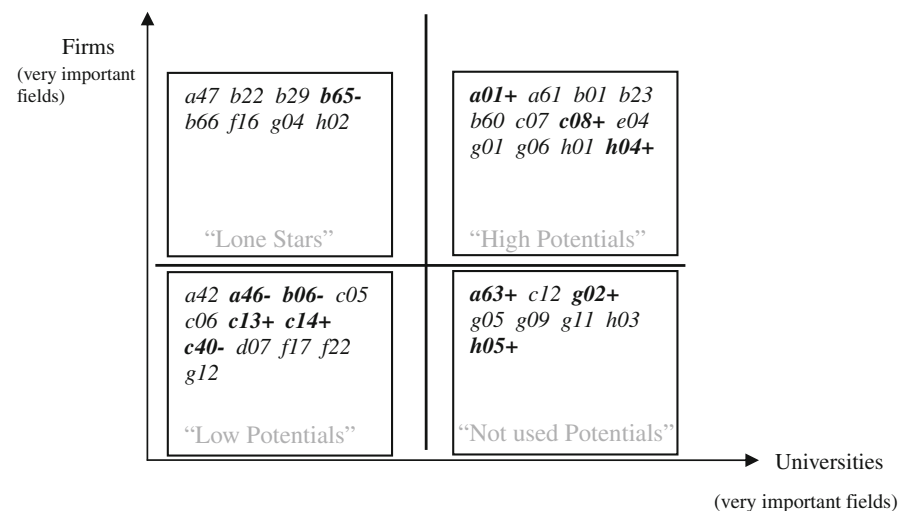

Fig. 2 Technological fields and the probability to have technology transfer. Firms with less than 500 employees. Note High potentials-upper right corner (technological fields frequently found in private enterprises and in universities). Low potentials-lower left corner (technological fields not frequently found in both private enterprises and universities). Not used potentials-lower right corner (frequently found at universities and not frequently found in private enterprises). Lone stars-upper left corner (frequently found in private enterprises and not frequently found at universities). Frequency refers to the 20 most important (according to counts in the respective technological field) or 20 least important technological fields. 'a47', 'b29', 'a01', etc. symbolize the technological field (see Table 11 in the Appendix for the description). Highlighted symbols identify technology fields with significant relations to the intensity of transfer activities. \pm indicates if the direction of the observed relationship

NetBreeze. ${ }^{17}$ Technology fields were assigned on the subclass level. Information on the subclass level was aggregated on the class level, and the section level following the official patent classification. The estimations were made on the class level. On the section level we have 8 different sections, and on the class level we found patent inscription of Swiss firms on 109 different classes. ${ }^{18}$ It is possible that one patent is assigned to different patent classes (technology fields). We screened 5,693 firms (Swiss Innovation Panel; 18 manufacturing industries, construction, and selected services) and found 34,048 patents (1904-2008 ${ }^{19}$; see Table 3). The 34,048 patents were assigned to 68,533 patent fields. $^{20}$

On the university side, we also assigned technology fields to science institutions of Swiss universities (ETH Zurich (including research institutes), EPF Lausanne, cantonal

\footnotetext{
${ }^{17}$ Based on the developed software we searched the espacenet.com website for the name of the firm and related patent information and saved the assigned patent classifications. For more information please see also http://www.netbreeze.ch on open source software.

${ }^{18}$ Sections: human necessities; performing operations, transporting; chemistry, metallurgy; textiles paper; fixed constructions; mechanical engineering, lighting, heating, weapons, blasting; physics; electricity. For the class level please refer to the Table 11 .

${ }^{19}$ We looked at the patent activities of a firm across its whole life span. The earliest patent of a sample firm we found in 1904. However, considerable patent activities of our panel firms (more than 1,000 annually) could have been detected from 1990 upwards. How is the possibility for changing fields accounted for? Since we are looking at the number of patent field inscriptions a change in the knowledge base of a firm is indicated through a greater number of patent field inscriptions in, let say a01 instead of b06. The longer time period make sense, since many firms file patents irregularly. Hence, unless we do not have more recent information, we assume that the patents granted so far indicate the knowledge base of the firm, even if patent activities lie back 10 years.

${ }^{20}$ It is likely that one patent is assigned to several patent fields. For example, if patent 1 is classified into, say both a01 and $\mathrm{c} 08$, the firm holding this patent would be recorded as having two "inscriptions", one in $\mathrm{a} 01$ and one in $\mathrm{c} 08$.
} 


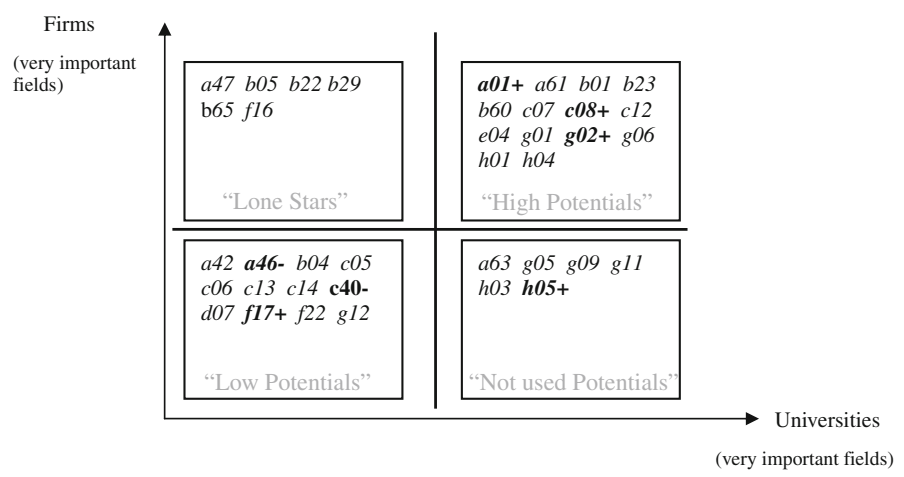

Fig. 3 Technological fields and the probability to have technology transfer. Firms with less than 300 employees. Note High potentials-upper right corner (technological fields frequently found in private enterprises and in universities). Low potentials-lower left corner (technological fields not frequently found in both private enterprises and universities). Not used potentials-lower right corner (frequently found at universities and not frequently found in private enterprises). Lone stars-upper left corner (frequently found in private enterprises and not frequently found at universities). Frequency refers to the 20 most important (according to counts in the respective technological field) or 20 least important technological fields.. 'a47', 'b29', 'a01', etc. symbolize the technological field (see Table 11 in the Appendix for the description). Highlighted symbols identify technology fields with significant relations to the intensity of transfer activities. tindicates if the direction of the observed relationship

universities, and universities of applied sciences). Since patent activities at Swiss universities are still rather decent and they do not represent their comprehensive research activities, ${ }^{21}$ we used the information on their websites about their research activities (websites were scanned in spring 2008). More concretely, we used a classifier that allow us to assign patent classifications to universities' research activities based on "terms" that could be found on the respective websites. The parameters of the classifier were developed and trained based on 150,000 patent description (see Lang 2008). ${ }^{22}$ The results of the technology field assignment (on the section level) to universities are found in Table 4. In Table 4 we see the number of websites searched for the universities respectively. Furthermore it shows the number of "hits" [classified websites (documents)] and how the "hits" could be allocated to patent sections. Thus "hits" are an absolute measure, indicating how often a patent classification could have been assigned to websites within the server domain of a university. In sum 62,742 websites have been searched and 40,193 websites could have been classified (hits). ${ }^{23}$

\footnotetext{
21 Patents mainly mirror research activities with short/middle-term market perspectives.

22 Technological fields are assigned based on a binary classificatory that follows a "cascade structure". For a detailed description of the classifier (classification procedures) and tests of robustness see Lang (2008).

${ }^{23}$ Certainly, one could think of other measures for technology knowledge residing within universities, e.g., budgets for technology fields. However, in order to match knowledge of enterprises with knowledge of firms we need to have an indicator available for both universities and enterprises. Budget figures on a technology field level are not available for firms. And also on the university side budgets for research in technology (patent) classes are not available. Since $8.6 \%$ of Swiss firms do also have transfer activities with foreign universities it would be interesting to take them into account as well. Unfortunately, we do not know with which universities in which countries firms have transfer activities. Thus, it is beyond our current means to look at the technology profile of universities in Germany, France, United Kingdom, USA, etc. Since $8.6 \%$ of Swiss firms do have transfer contacts with foreign universities it is likely that there is a considerable amount of technology spill-in from foreign universities.
} 
Secondly, we collected data in the course of a survey among Swiss enterprises about their transfer activities with universities. The survey was conducted in 2005 and mainly covers the time period 2002-2005. ${ }^{24}$ From this survey we used the information about the intensity of transfer activities, the industry affiliation of firms, firm size, patent activities, education level of the employees, and whether a firm is foreign-owned. The survey was based on a (with respect to firm size) disproportionately stratified random sample of firms with at least 5 employees covering all relevant industries of the manufacturing sector, the construction sector and selected service industries (excluding industries with an expected very low propensity of KTT activities such as hotels/catering, retail trade, real estate/leasing, personal services). Answers were received from 2,582 firms, i.e., $45.4 \%$ of the firms in the underlying sample. The response rates do not vary much across industries and size classes with a few exceptions (over-representation of wood processing, energy industry and machinery, under-representation of clothing/leather industry). The non-response analysis (based on a follow-up survey of a sample of the non-respondents) did not indicate any serious selectivity bias with respect to the incidence of transfer activities with universities/ science institutions. In a further step we matched the information from the survey with the patent information on the firm-level and received a combined data set of 2,132 observations.

\section{Results}

The main results are presented in Tables 5, 6, 7 and Figs. 1, 2, 3. ${ }^{25}$ Only if the coefficient of the technology field is significant the estimation results are presented in Tables 5, 6, and 7. The overlap of technology fields between private enterprises and universities is considerable. Depending on the firm-size between 12 and 14 (out of 20) technology fields are considered to be important for private enterprises and universities. Furthermore, it was found that the technological activities of universities and the technological orientation of firms are an important factor for knowledge and technology transfer, especially for smaller firms. This fact is mostly neglected in related studies. Tables 8, 9, and 10 show the technological fields with a significant impact on firms' transfer intensity and the sectors with a relative great patent share in the technology field respectively. We present the results for "all firms", for "firms with less than 500 employees", and for "firms with less than 300 employees" ${ }^{26}$ For "all firms" we see that 10 technology fields are significant (see Table 8), for firms with less than 500 employees we see that 12 technology fields are

\footnotetext{
${ }^{24}$ However, some questions do not refer to a certain time period, e.g., the question for technology transfer activities with universities refers to two periods "2002-2004" and "before 2002". If a firm had transfer activities in one of the two periods the firm was identified as transfer active. If a firm was transfer active we asked for the transfer partner. The number of different transfer partners is our measure for transfer intensity (intense; see Table 1).

25 The following test of robustness has been conducted: I limited the sample to those firms that filed patents between 1988 and 2008 (20 years). I discounted patents (technology fields) filed between 1988 and 1992 with the factor 0.25. Patents filed between 1993 and 1997 were discounted with the factor 0.5. Patents filed between 1998 and 2002 were discounted with the factor 0.75 . Patents filed after 2003 were not discounted. Results: first, the number of observation hardly changes [2,099 (after correction), 2,132 (before correction)]. This means that most of the firms that had patent activities before 1988 have had patent activities after 1988 as well. Secondly, the results are very similar. What changes? Low potentials (all firms): c13 moved from significant plus to insignificant. Low potentials (<300 employees): c13 and c14 moved from not significant to significant plus. Lone stars (<300 employees): b65 moved from not significant to significant minus. Thirdly, this indicates a path dependency of knowledge creation within a firm.

${ }^{26}$ For a complete description of the technological fields please refer to Table 11.
} 


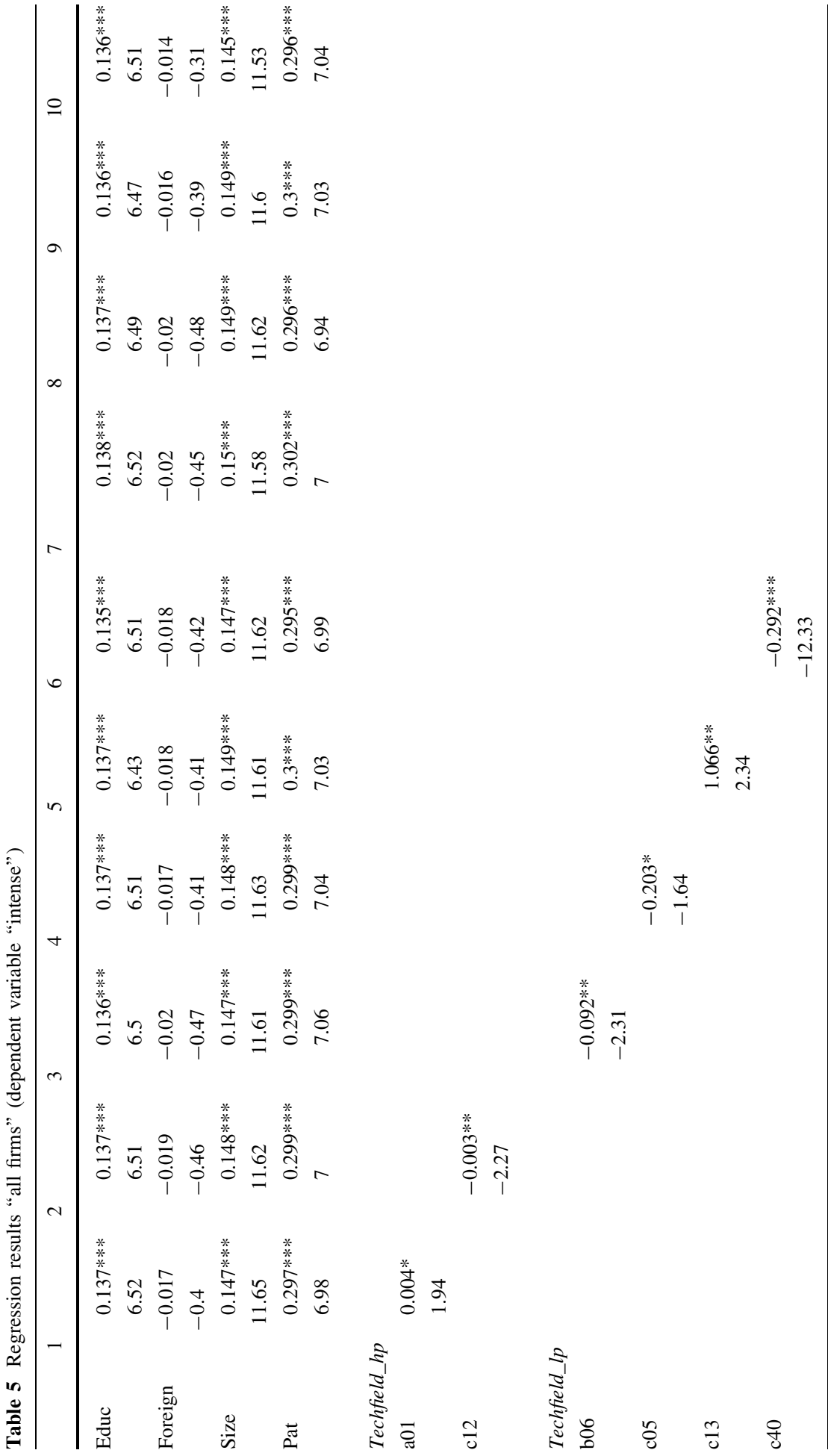




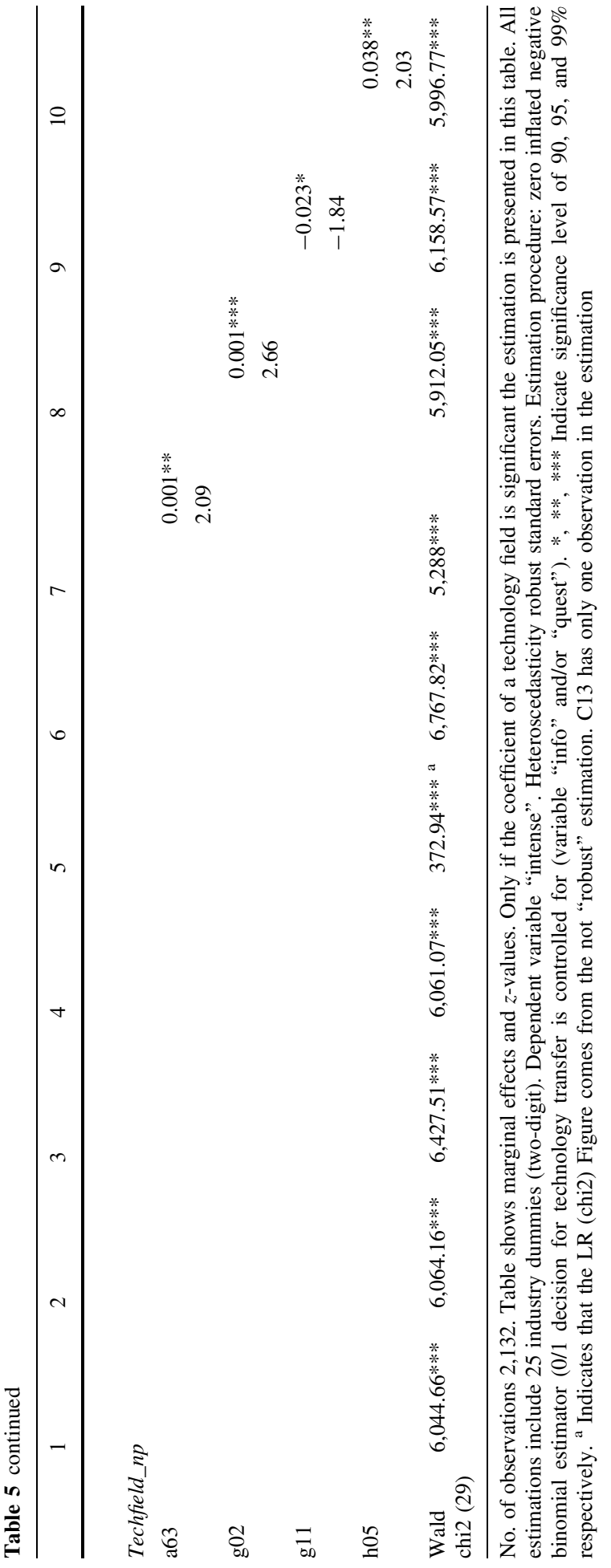




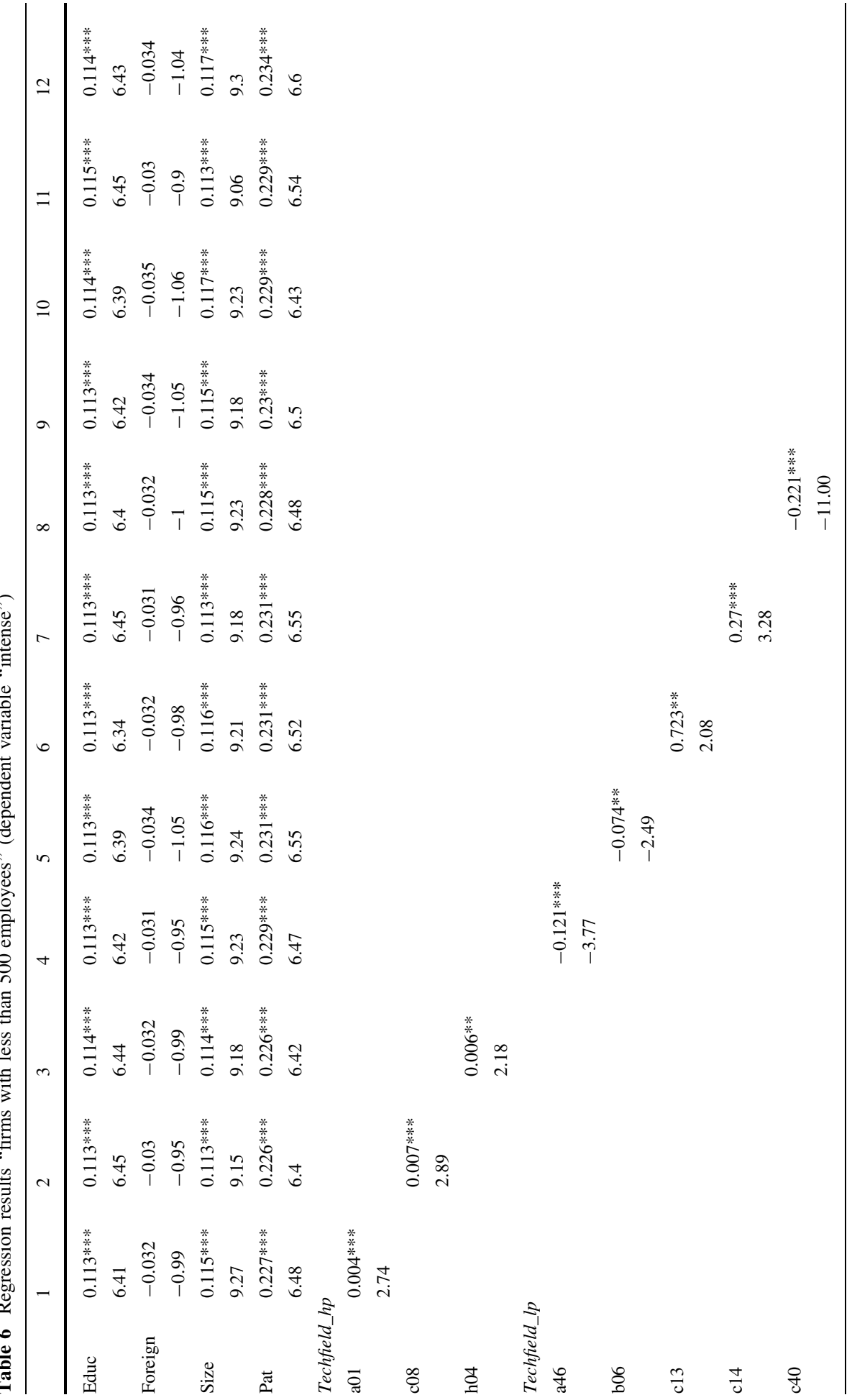




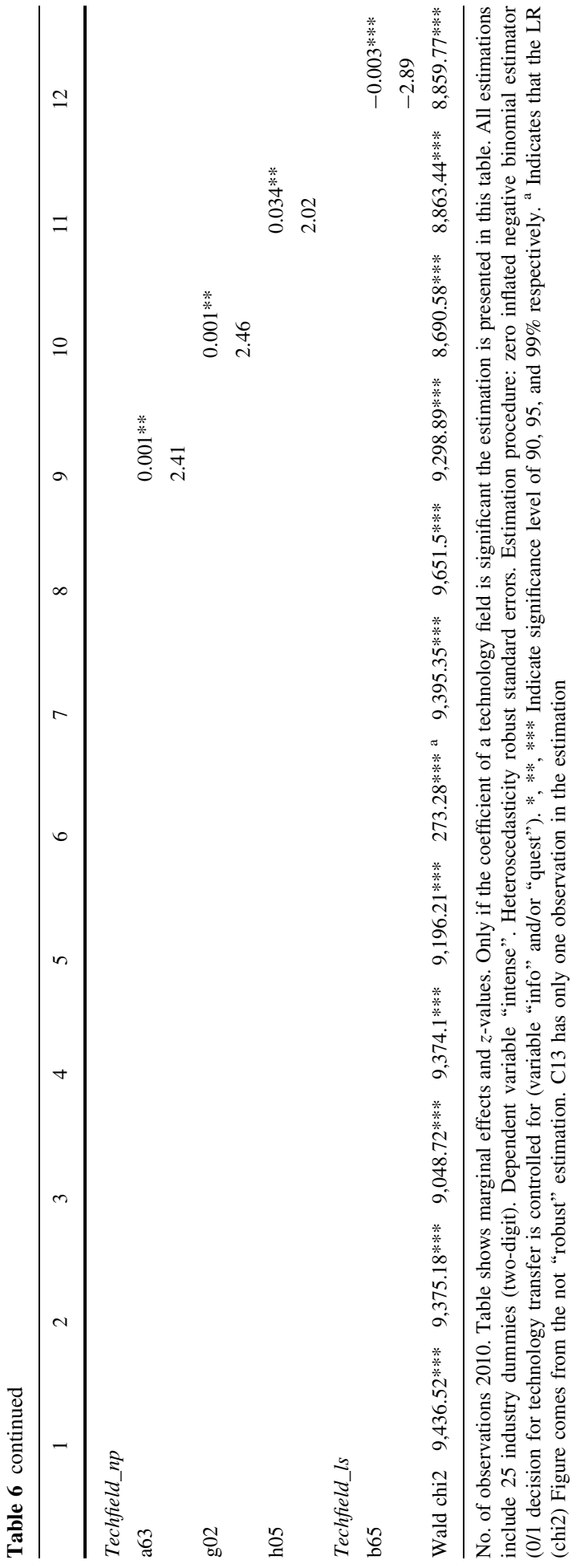




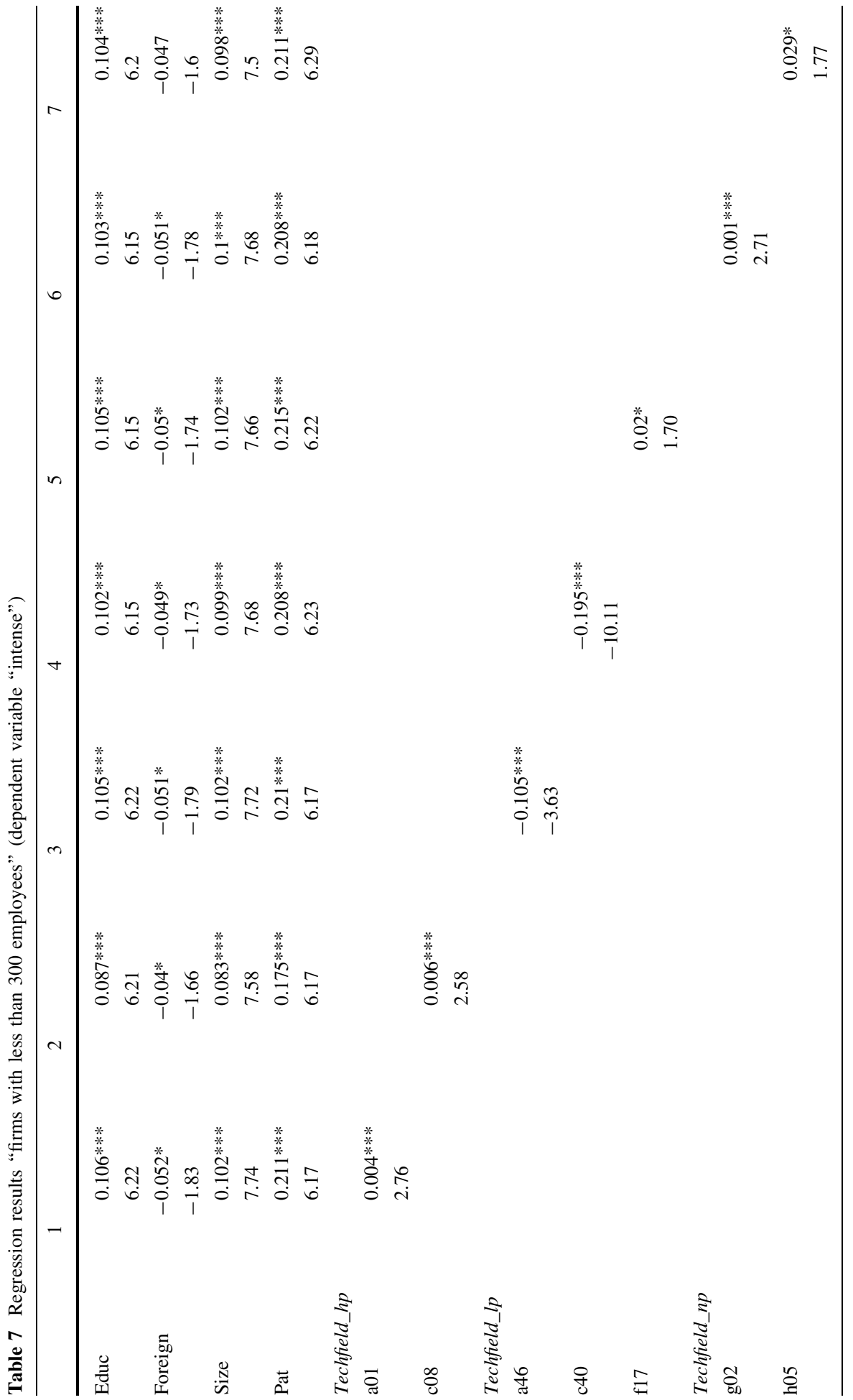




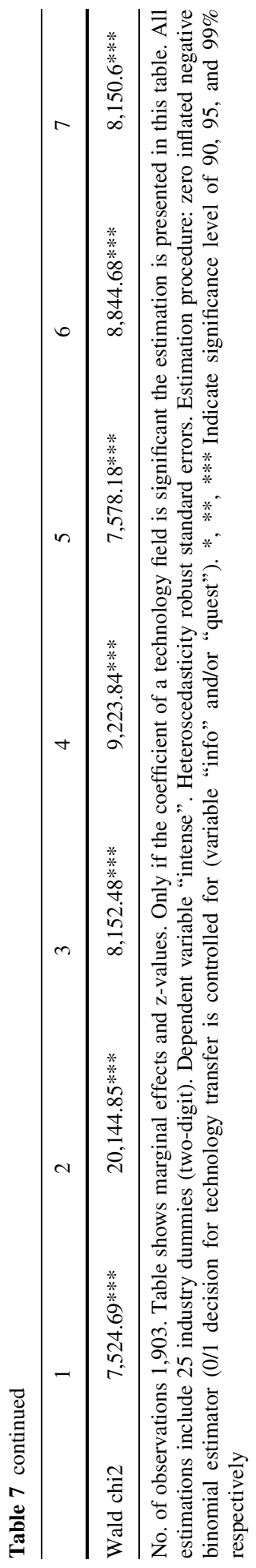


Table 8 Significant and not significant technological fields-all firms

Significant results Not significant results

High potentials

$\mathrm{a} 01+$ Machinery, chemicals, metalworking

c12- Chemicals, construction, food/ beverage, machinery, electrical machinery

Low potentials

b06- Machinery, electronics/instruments, chemicals, electrical machinery

c05- Chemicals, machinery, electrical machinery, wholesale, banking/ insurance

c13+ Food/beverage

c40- Construction

Not used potentials

a63+ Machinery, metalworking, other manufacturing

g02+ Electronics/instruments, machinery, electrical machinery

g11- Electronics/instruments, machinery, electrical machinery

h05+ Machinery, electrical machinery, electronics/instruments

Lone Stars a61 Chemicals, electronics/instruments, machinery

b01 Machinery, chemicals, electronics/instruments

b23 Machinery, metalworking, electronics/instruments

b60 Machinery, electronics/instruments, electrical machinery

c07 Chemicals, machinery, electrical machinery, construction

c08 Chemicals, machinery, electrical machinery

g01 Machinery, electronics/instruments, electrical machinery

g06 Machinery, electronics/instruments, electrical machinery

h01 Electronics/instruments, machinery, electrical machinery

h04 Electronics/instruments, electrical machinery, machinery

c06 Machinery, chemicals, electrical machinery

c14 Food/beverage, chemicals, metal, machinery

d07 Electrical machinery, metalworking, machinery

f17 Machinery, chemicals, metalworking, electronics/ instruments, other manufacturing, construction, banks/insurance

f22 Machinery, metalworking, electrical machinery

g12 Electronics/instruments, metalworking, business services

e04 Machinery, metalworking, construction

g05 Machinery, electronics/instruments, electrical machinery

g09 Machinery, electronics/instruments, watches, other manufacturing, paper, computer services

h03 Electronics/instruments, electrical machinery, machinery, computer services

a47 Machinery, other manufacturing, metalworking

b29 Machinery, chemicals, electronics/instruments

b66 Machinery, electronics/instruments, electrical machinery, construction, wholesale 
Table 8 continued

\begin{tabular}{ll}
\hline Significant results & Not significant results \\
\hline b65 Machinery, electronics/instruments, chemicals \\
c09 Chemicals, machinery, electrical machinery, \\
f16 $\quad$ Machinery, electronics/instruments, metalworking \\
h02 Machinery, electronics/instruments, electrical \\
g04 Wachinery \\
atches, electronics/instruments, machinery, \\
electrical machinery
\end{tabular}

This table shows significant and not significant "technology fields" for transfer activities of firms separated into the four categories (high potentials, low potentials, lone stars, and not used potentials). Furthermore the important sectors are listed (according number of firms that filed patents in the respective technology field)

significant (see Table 9), and for firms with less than 300 employees we see that 7 technology fields are significant (see Table 10).

Combining our findings about the overlap of technology fields with the econometric estimations enables us to answer our hypothesis (see Tables 5, 6, 7; Figs. 1, 2, 3).

With hypothesis 1 (H1) we refer to "high potentials". Looking at the category "all firms" we see that especially R\&D activities in the following fields are found in private enterprises as well as universities (high potentials; see Fig. 1):

- human necessities, i.e., agriculture (a01), medical or veterinary sciences or hygiene (a61)

- performing operations/transporting, i.e., physical or chemical processes (b01), hand tools, workshop equipment, manipulators (b23), vehicles in general (b60)

- chemistry, i.e., organic chemistry (c07), organic macromolecular compounds (c08), biochemistry, microbiology (c12)

- physics, i.e., measuring (counting), testing (g01), computing, calculating, counting (g06)

- electricity, i.e., basic electric elements (h01), and electric communication technique (h04)

Comparing these results with the results from the econometric analysis (see Table 5; Fig. 1) we see that private enterprises patenting in the field a01 have a significant greater propensity to conduct technology transfer activities with different universities (greater intensity), while firms that emphasize c12 have a relatively low transfer propensity. Especially firms in the machinery industry and chemical industry as well as metal products were filing patents in a01. C12 is mainly researched by firms in the chemical industry. All other fields are not significant.

Constraining our sample to firms with less than 500 employees leads to some important changes (see Table 6; Fig. 2); c12 switches to the category not used potentials and e04 (building-layered materials, layered products in general) is new among the high potentials. Furthermore, firms with less than 500 employees have a greater probability to have intensive transfer activities in three out of 12 high potentials (h04, c08, a01). This indicates that "smaller" firms $(<500)$ make more intensive use of academic research in these technological areas (high potentials). This shows that the concept of "absorptive capacity" is a necessary but clearly not a sufficient condition for transfer activities if we assume that 
Table 9 Significant and not significant technological fields-firms with less than 500 employees

\begin{tabular}{|c|c|c|}
\hline Significant results & \multicolumn{2}{|c|}{ Not significant results } \\
\hline \multicolumn{3}{|l|}{ High potentials } \\
\hline $\begin{array}{c}\text { h04+ Electronics/instruments, electrical } \\
\text { machinery, computer services }\end{array}$ & g06 & $\begin{array}{l}\text { Electronics/instruments, machinery, electrical } \\
\text { machinery, computer services }\end{array}$ \\
\hline $\begin{array}{l}\text { c08+ Machinery, chemicals, electrical } \\
\text { machinery }\end{array}$ & a61 & Chemicals, electronics/instruments, machinery \\
\hline \multirow[t]{7}{*}{$\begin{array}{l}\text { a01+ Machinery, metalworking, chemicals, } \\
\text { electrical machinery, construction }\end{array}$} & h01 & $\begin{array}{l}\text { Electronics/instruments, machinery, electrical } \\
\text { machinery }\end{array}$ \\
\hline & $\mathrm{g} 01$ & $\begin{array}{l}\text { Machinery, electronics/instruments, electrical } \\
\text { machinery }\end{array}$ \\
\hline & $\mathrm{c} 07$ & Chemicals, machinery, electrical machinery \\
\hline & $\mathrm{e} 04$ & $\begin{array}{l}\text { Metalworking, machinery, food/beverage, } \\
\text { electronics/instruments, other manufacturing, } \\
\text { construction }\end{array}$ \\
\hline & b01 & Machinery, chemicals, electronics/instruments \\
\hline & b23 & Machinery, metalworking, electronics/instruments \\
\hline & b60 & $\begin{array}{l}\text { Machinery, electronics/instruments, metalworking, } \\
\text { electrical machinery, other manufacturing, } \\
\text { construction }\end{array}$ \\
\hline
\end{tabular}

Low potentials

a46- Electronics/instruments, food/beverage, d07 Electrical machinery, metalworking, machinery construction, transport/ telecommunication

b06- Machinery, electronics/instruments, electrical machinery

c13+ Food/beverage

c14+ Food/beverage, metalworking, machinery

c40- Construction

f17 Machinery, chemicals, metalworking, other manufacturing, construction

g12 Electronics/instruments, metalworking, business services

c05 Chemicals, machinery, electrical machinery, wholesale, banking/insurance

c06 Chemicals, machinery, electrical machinery

f22 Machinery, metalworking, electrical machinery

Not used potentials

a63+ Machinery, other manufacturing, metalworking, construction

g02+ Electronics/instruments, electrical machinery, machinery

h05+ Electrical machinery, machinery, electronics/instruments

g09 Machinery, electronics/instruments, paper, watches, other manufacturing, computer services

c12 Construction, chemicals, food/beverage, machinery, electrical machinery

g11 Machinery, electrical machinery, electronics/ instruments, construction

h03 Electronics/instruments, electrical machinery, machinery, computer services

g05 Machinery, electronics/instruments, electrical machinery, computer services

Lone Stars

b65- Machinery, chemicals, electronics/ instruments

f16 Machinery, electronics/instruments, metalworking 
Table 9 continued

\begin{tabular}{|c|c|c|}
\hline \multirow[t]{2}{*}{ Significant results } & \multicolumn{2}{|c|}{ Not significant results } \\
\hline & $\mathrm{b} 22$ & $\begin{array}{l}\text { Machinery, electronics/instruments, synthetics, } \\
\text { metal, metalworking, electrical machinery, other } \\
\text { manufacturing, wholesale, computer services, }\end{array}$ \\
\hline & g04 & $\begin{array}{l}\text { Watches, electrical machinery, electronics/ } \\
\text { instruments }\end{array}$ \\
\hline & b29 & Machinery, chemicals, electronics/instruments \\
\hline & $\mathrm{a} 47$ & $\begin{array}{l}\text { Machinery, other manufacturing, chemicals, } \\
\text { metalworking }\end{array}$ \\
\hline & b66 & $\begin{array}{l}\text { Machinery, electronics/instruments, electrical } \\
\text { machinery, construction, wholesale }\end{array}$ \\
\hline & $\mathrm{h} 02$ & $\begin{array}{l}\text { Machinery, electronics/instruments, electrical } \\
\text { machinery }\end{array}$ \\
\hline $\begin{array}{l}\text { b65- Machinery, chemicals, electronics/ } \\
\text { instruments }\end{array}$ & $\mathrm{f} 16$ & Machinery, electronics/instruments, metalworking \\
\hline
\end{tabular}

This table shows significant and not significant "technology fields" for transfer activities of firms separated into the four categories (high potentials, low potentials, lone stars, and not used potentials). Furthermore the important sectors are listed (according number of firms that filed patents in the respective technology field)

larger firms have a greater absorptive capacity (on average) compared to smaller ones. Smaller firms are likely to have a greater need (lack of internal scope of resources) to collaborate with universities and thus lower absorptive capacity might be compensated through greater need. Firms in the electronic/instruments industry, the electronic industry, and informatics/R\&D industry are mainly filing patents in h04. Firms in the chemical industry, machinery and electronic have the greatest number of patent field inscriptions in c08. Like in the category "all firms", the chemical industry, metal products and machinery are dominant in a01.

If we further constrain our firm sample to firms with less than 300 employees (see Table 7; Fig. 3) we not only find e04 and again c12 among the high potentials, but newly also g02 (optics, making optical elements or apparatus); three out of fourteen technological fields show a significant positive impact on the intensity of transfer activities (a01, c08, g02). These are relatively few compared to firms with less than 500 employees but more than "all firms". Thus our result that smaller firms have relatively more transfer contacts within the "high potentials" still holds. However, it should be noticed that there is a slight shift in significance; g02 (optics) is only significant in the category " $<300$ ", while h04 (electric communication technique) is only significant in the category " $<500$ ". Only a01 remains significant in all three size categories. Machinery and chemical industry are amongst the dominant industries in 08 and in g02 mainly firms in electronics and machinery industry are filing patents.

With hypothesis 2 (H2) we refer to "low potentials". Starting again with the category "all firms" we see few patent field inscriptions on both sides of private enterprises and universities, in the following fields (see Fig. 1):

- Human necessities, i.e., headwear (a42)

- performing operations/transporting, i.e., generating or transmitting mechanical vibrations (b06) 
Table 10 Significant and not significant technological fields-firms with less than 300 employees

Significant results Not significant results

High potentials

$\mathrm{a} 01+$ Synthetics, metal, watches, transport/ telecommunication, banking/insurance

c08+ Machinery, chemicals, synthetics, computer services

$\mathrm{g} 02+$ Electronics/instruments, machinery, construction

Low potentials

a46- Electronics/instruments, food/beverage, a42 construction, transport/ telecommunication

c40- Construction

f17+ Machinery, metalworking, other manufacturing, construction

Not used potentials

h05+ Machinery, electronics/instruments, electrical machinery a61 Chemicals, electronics/instruments, machinery

b01 Machinery, chemicals, electronics/instruments

b23 Machinery, metalworking, electronics/instruments

b60 Machinery, electronics/instruments, metalworking, construction

c07 Chemicals, machinery, construction

c12 Construction, chemicals, machinery

e04 Metalworking, machinery, electronics/instruments, construction

g01 Electronics/instruments, machinery, computer services

g06 Electronics/instruments, machinery, computer services

h01 Electronics/instruments, machinery, electrical machinery

h04 Electronics/instruments, computer services, food/ beverage, machinery, electrical machinery

b04 Machinery, metal, electronics/instruments

c05 Machinery, electrical machinery, wholesale, banking/insurance

c06 Chemicals, machinery

c13 Food/beverage

c14 Metal

d07 Metalworking, machinery, electrical machinery

g12 Electronics/instruments, metalworking

f22 Machinery, metalworking

a63 Machinery, other manufacturing, construction

g05 Machinery, electronics/instruments, computer services

g09 Machinery, electronics/instruments, computer services

g11 Machinery, electrical machinery, electronics/ instruments, construction

h03 Electronics/instruments, computer services, machinery, electrical machinery 
Table 10 continued

\begin{tabular}{|c|c|c|}
\hline \multirow[t]{2}{*}{ Significant results } & \multicolumn{2}{|c|}{ Not significant results } \\
\hline & $\mathrm{a} 47$ & $\begin{array}{l}\text { Machinery, other manufacturing, chemicals, } \\
\text { metalworking }\end{array}$ \\
\hline & b05 & $\begin{array}{l}\text { Machinery, food/beverage, electrical machinery, } \\
\text { electronics/instruments, other manufacturing, } \\
\text { computer services }\end{array}$ \\
\hline & b22 & $\begin{array}{l}\text { Machinery, electronics/instruments, synthetics, } \\
\text { metal, metalworking, electrical machinery, other } \\
\text { manufacturing, construction, wholesale, computer } \\
\text { services }\end{array}$ \\
\hline & b29 & Machinery, electronics/instruments, chemicals \\
\hline & b65 & $\begin{array}{l}\text { Machinery, electronics/instruments, food/beverage, } \\
\text { chemicals }\end{array}$ \\
\hline & $\mathrm{f} 16$ & Machinery, metal, electronics/instruments \\
\hline
\end{tabular}

This table shows significant and not significant "technology fields" for transfer activities of firms separated into the four categories (high potentials, low potentials, lone stars, and not used potentials). Furthermore the important sectors are listed (according number of firms that filed patents in the respective technology field)

- chemistry, i.e., manufacturing of fertilizers (c05), explosives, matches (c06), sugar industry-polysaccharides (c13), skins, hides, pelts, leader (c14), combinatorial technology (c40)

- Textiles, paper, i.e., robes, cables other than electric (d07)

- Mechanical engineering, i.e., storing or distributing gases or liquids (f17), steam generation-physical or chemical apparatus (f22)

- Physics, i.e., instrument details (g12)

Taking into account the econometric analysis (see Table 5; Fig. 1) we see that firms active in these technological fields refrain from transfer activities with universities by trend; for three classifications we observe a negative sign (b06, c05, c40), one is positive (c13) and the rest is insignificant. Firms in the electronic and machinery industry are frequently filing patents in b06 and c05. In c40 and c13 we have only one (firm) observation respectively. This does not provide us with a strong result.

Looking at firms with less than 500 employees we have quite similar results (see Table 6; Fig. 2). The technological fields are identical-only significant signs switch to some extent; a46 (brushware), b06, and c40 are significant negative and c13 and c14 are significant positive. Again, we have very few observations (in brackets) in c13 (1) and c40 (1), but also in c14 (3). Again, machinery (b06) and electronics (a46, b06) are frequently filing patents in these technology fields.

The main results still holds if we restrain our sample to firms with less than 300 employees (see Table 7; Fig. 3). Only one new technological field (b04-centrifugal apparatus and machines for carrying-out physical or chemical processes) can be observed. Also machinery and electronics remain important industries in terms of filing patents in significant technology fields (a46, f17). In sum it is obvious that we do not observe-like expected-transfer activities in "low potentials".

With hypothesis 3 (H3) we refer to "lone stars". Starting again with the results for "all firms" we see that private enterprises emphasis in their patent activities a number of 
technology fields that are not emphasized or less emphasized by universities, like follows (see Fig. 1):

- Human necessities, i.e., furniture, domestic articles and appliances, coffee mills, spice mills, suction cleaners in general (a47)

- Performing operations/transporting, i.e., working of plastics (b29), conveying, packing, storing, handling thin or filamentary material (b65), hoisting, lifting, hauling (b66)

- Chemistry, i.e., dyes, paints, polishes, natural resins, adhesives (c09)

- Mechanical engineering, i.e., engineering elements/units, measures for producing and maintaining effective functioning of machines or installations, thermal insulation (f16)

- Physics, i.e., horology (g04)

- Electricity, i.e., generation, conversion, or distribution of electric power (h02)

Considering the econometric estimations (see Table 5; Fig. 1) we see that private enterprises patenting in these technology fields do not have a tendency for or against technological transfer activities in general; none of these technological fields are significant. This result is quite intuitive if it is considered that universities do few or no research in these technology fields. Thus, firms might have problems to find adequate partners. Which industries are predominantly active in those technological fields? Machinery, other industries, electronics, chemistry, and the watch industry are mainly filing patents in those fields.

Focusing on firms with less than 500 employees the results change slightly (see Table 6; Fig. 2); only one technological field (b65) has a significant negative sign. All other are insignificant and thus confirming the results for "all firms". Furthermore, b22 (casting, powder metallurgy) is substituting c09. The list of important industries for "lone stars" remains identical to "all firms".

For firms with less than 300 employees we found fewer technological fields (see Table 7; Fig. 3). h02, g04, and b66 can not be found anymore among this group and b05 (spraying or atomizing in general, applying liquids or other fluent materials to surfaces) is new. The composition of important industries for these technological fields does not change.

With hypothesis 4 (H4) we refer to "not used potentials". This group and the group of "high potentials" are of special interest for policy makers. Here, universities show considerable research activities but firms seem to be less interested in such research or do not have the absorptive capacity. Referring to "all firms" the following technological fields are classified as "not used potentials" (see Fig. 1):

- Human necessities, i.e., sports, games, and amusements (a63)

- Fixed constructions, i.e., building-layered materials, layered products in general (e04)

- Physics, i.e., optics-making optical elements or apparatus (g02), controlling, regulating (g05), educating, cryptography, display, advertising, seals (g09), information storage (g11)

- Electricity, i.e., basic electronic circuitry (h03), electric techniques not otherwise provided for (h05)

As expected we have predominantly significant positive or not significant results for "not used potentials" (see Table 5; Fig. 1). This indicates that firms' do not have comprehensive research activities in these fields but try to build in-house capabilities through transfer activities with universities. This supports the explorative character of these transfer contacts (see March 1991). In case of not significant results or negative significant results firms do not have the absorptive capacity to make use of public research activities or they simply do not want (e.g., because of security reasons) to have transfer activities in such technology fields. Referring to all firms we see only one technology field with a significant 
negative sign (g11). That means, although universities have considerable research activities in $\mathrm{g} 11$, private enterprises do not tend to have transfer activities; secrecy, different (time) priorities, or problems for commercializing results could be reasons for it. Firms from the machinery, metal products, electronics, and electrical engineering business are most frequently filing patents in these technological fields.

Looking at firms with less than 500 employees we see very similar results (see Table 6; Fig. 2). Only e05 is substituted by c12 (biochemistry, beer, spirits, wine, microbiology) and g11 is no longer significant. All other variables remain to be significant positive or not significant. Also in terms of active industries, we do not see considerable differences. Machinery, electrical engineering and electronics are still very important industries. In addition, chemistry and construction (in case of c12, and a63) gain some importance as well.

In the category "firms with less than 300 employees" we still get similar results compared to "less than 500 employees" and "all firms" (see Table 7; Fig. 3). The technological fields are significant positive (h05) or not significant. However, we find fewer technological fields (without c12, e04 and g02) and a63 is no longer significant positive. Again machinery, electronics and electrical engineering are mainly filing patents in these technological fields. Other industries and construction gain some importance.

In the empirical estimations we controlled for the education-level of firms (educ), firm size (size), whether firms have patent activities (pat), and whether firms are foreign owned (foreign). The education-level, firm size, and patent activities are significantly positive correlated with transfer intensity in all estimations (see Tables 5, 6, 7). Foreign owned firms show lower transfer intensity compared to domestic firms for firms with less than 300 employees (see Table 7). In all other estimations being foreign-owned is insignificant. These results clearly indicate that the "absorptive capacity" plays an important role for transfer intensity. Furthermore it is important to control for patent activities of a firm. Otherwise technology field variables would merely indicate whether a firm has patent activities or not.

\section{Conclusions}

This study tries to map the technology activities of private enterprises and the technology activities of universities in Switzerland in order to detect collaboration potential or knowledge and technology transfer potential between private enterprises and universities. This way we can improve the knowledge base for policy making. For this study we used two data sources. Firstly, and in co-operation with NetBreeze, ${ }^{27}$ we assigned technology fields to R\&D active Swiss firms and Swiss universities. Secondly, we collected data in the course of a survey among Swiss enterprises about their transfer activities with universities. We received answers from 2,582 firms, i.e., $45.4 \%$ of the firms in the underlying sample.

Looking at the technology proximity between private enterprises and universities we can identify four areas. Firstly, "high potentials" (technology fields frequently found in private enterprises and at universities). Secondly "low potentials" (technology fields not frequently found in private enterprises and at universities). Thirdly, "not used potentials" (technology fields frequently found at universities and not frequently found in private enterprises). Fourthly "lone stars" (technology fields frequently found in private enterprises and not frequently found at universities).

${ }^{27}$ NetBreeze is an ETH spin-off that developed an internet search engine (http://www.netbreeze.ch/ index.php?id=23). 
We saw that great technology proximity between universities and private enterprises increases the probability of transfer activities and makes it more likely to have more than one university link. This was observed in several technology fields, like a01 (agriculture), c08 (organic macromolecular compounds), g02 (optics), and h04 (electric communication technique) and especially in smaller firms (less than 500 employees or less than 300 employees). These findings are very much in line with the concept of absorptive capacity and/or a resource based motivation for transfer activities and these alliances have a more knowledge 'exploiting' character.

It was also found that there are not transfer activities in technology fields that are not important (not frequently researched) for both private enterprises, and universities. Here, we mainly observed - independent of the size class — not significant or negative significant relationships between the respective technology fields and the probability to have comprehensive transfer contacts. This result is quite coherent, if we think that both sides do not emphasize research in these fields and thus do not accumulate considerable knowledge.

Furthermore, it became obvious that firms do not have transfer activities with universities in technology fields that are frequently researched by private enterprises and not frequently researched at universities. We did not observe significant transfer activities in those fields (one exception) independent of the size class. It is understandable that private enterprises refrain from transfer activities if they feel to have "better" knowledge compared to potential partners at universities.

It was also found that firms want to change or essentially modify their technology orientation with different partners form universities. These findings refer to technology fields in the category "not used potentials". As expected we saw predominantly significant positive or not significant transfer relationships in those fields. The significant positive technology fields also indicate that private enterprises recognize the relevance of transfer activities to change or essentially modify their knowledge base. This type of transfer contacts emphasizes the more explorative style of the knowledge seeking process from a firm's perspective. This incorporates a "technology-push" effect from universities to the private sector contributing to the competitiveness of the private transfer partner.

Since we know that transfer activities support the innovativeness and productivity of firms, it is useful to develop policy measures to ease transfer-especially for smaller firms - by taking into account the different functions of private enterprises and universities in the society. From a policy point of view all four fields can be of interest. However, more detailed investigations of the transfer potential of specific technology fields are necessary in order to identify a suboptimal level of transfer activities. The rather rough identification of "high potentials", "low potentials", "lone stars", and "not used potentials" only allows for some general policy remarks. Thus, it seems to be obvious that a lack of transfer activities in some fields of "high potentials" poses a communication/information challenge to transfer policy makers. Firms may not be well informed about research activities in related fields at universities or research goals, time schedules, or the research questions are too different and thus firms refrain from transfer activities. Secrecy may be a further problem, especially in very market related research. A lack of transfer activities in "low potentials" is quite understandable, since there seems to be neither an academic research interest nor any commercial interest. Thus, "low potentials" are of no or low policy interest at least in the short-term. However, "low potentials" can pose long-term strategic challenges, in case the government aims at strengthening the capabilities in such technology fields, if, for instance, promising long-term benefits are likely for the society (e.g., combinatorial technologies). "Lone stars" may have problems to find adequate national academic partners for their research activities, which would pose an information challenge 
to policy makers or a research strategy challenge to universities, if such technology fields are of academic interest as well. It should be obvious that universities should not take over research goals from the private sector if there is not any academic research interest. "Not used potential" indicates a lack of absorptive capacity or a lack of commercial potential. "Not used potentials" may signalize a communication problem between universities and the private sector or it may indicate that research in those fields is simply of less commercial value at least in the short-term. However, the transfer potential of technology fields should be investigated in more detailed empirical analyses. Furthermore, the study suggests monitoring the technological orientation of firms and universities and comparing their profiles regularly. This would provide policy makers with a sound basis for technology oriented policy initiatives.

Acknowledgments I am grateful for insightful comments and discussions on earlier drafts from Spyros Arvanitis. I am also grateful to Joel Lang for the programming of the algorithm to search patent descriptions and to provide descriptive statistics, to François Ruef and Leo Keller for discussions on framing the technology orientation of firms, and to Eric Schwegler for helping me to compile the data. Mistakes are the author's alone. This study was funded by the ETH Board in Switzerland.

\section{Appendix}

See Table 11.

Table 11 Patent classes found for Swiss firms

\begin{tabular}{|c|c|}
\hline Class & Description \\
\hline $\mathrm{a} 01$ & AGRICULTURE; FORESTRY; ANIMAL HUSBANDRY; HUNTING; TRAPPING; FISHING \\
\hline $\mathrm{a} 22$ & BUTCHERING; MEAT TREATMENT; PROCESSING POULTRY OR FISH \\
\hline a23 & FOODS OR FOODSTUFFS; THEIR TREATMENT, NOT COVERED BY OTHER CLASSES \\
\hline a24 & TOBACCO; CIGARS; CIGARETTES; SMOKERS’ REQUISITES \\
\hline a42 & HEADWEAR \\
\hline a43 & FOOTWEAR \\
\hline a44 & HABERDASHERY; JEWELLERY \\
\hline $\mathrm{a} 46$ & BRUSHWARE \\
\hline a47 & $\begin{array}{l}\text { FURNITURE (arrangements of seats for, or adaptation of seats to, vehicles B60 N); DOMESTIC } \\
\text { ARTICLES OR APPLIANCES; COFFEE MILLS; SPICE MILLS; SUCTION CLEANERS IN } \\
\text { GENERAL (ladders E06C) }\end{array}$ \\
\hline a61 & MEDICAL OR VETERINARY SCIENCE; HYGIENE \\
\hline a62 & LIFE-SAVING; FIRE-FIGHTING (ladders E06C) \\
\hline a63 & SPORTS; GAMES; AMUSEMENTS \\
\hline b01 & $\begin{array}{l}\text { PHYSICAL OR CHEMICAL PROCESSES OR APPARATUS IN GENERAL (furnaces, kilns, } \\
\text { ovens, retorts, in general F27) }\end{array}$ \\
\hline b02 & $\begin{array}{l}\text { CRUSHING, PULVERISING, OR DISINTEGRATING; PREPARATORY TREATMENT OF } \\
\text { GRAIN FOR MILLING }\end{array}$ \\
\hline b03 & $\begin{array}{l}\text { SEPARATION OF SOLID MATERIALS USING LIQUIDS OR USING PNEUMATIC TABLES } \\
\text { OR JIGS; MAGNETIC OR ELECTROSTATIC SEPARATION OF SOLID MATERIALS FROM } \\
\text { SOLID MATERIALS OR FLUIDS; SEPARATION BY HIGH-VOLTAGE ELECTRIC FIELDS } \\
\text { (separating isotopes B01D 59/00; crushing or disintegrating B02C; centrifuges or vortex apparatus } \\
\text { for carrying out physical processes B04) }\end{array}$ \\
\hline b04 & $\begin{array}{l}\text { CENTRIFUGAL APPARATUS OR MACHINES FOR CARRYING-OUT PHYSICAL OR } \\
\text { CHEMICAL PROCESSES }\end{array}$ \\
\hline
\end{tabular}


Table 11 continued

\section{Class Description}

b05 SPRAYING OR ATOMISING IN GENERAL; APPLYING LIQUIDS OR OTHER FLUENT MATERIALS TO SURFACES, IN GENERAL (domestic cleaning A47L; cleaning in general by methods essentially involving the use or presence of liquid B08B 3/00; sand-blasting B24C; coating of articles during shaping of substances in a plastic state B29C 39/10, B29C 39/18, B29C 41/20, B29C 41/30, B29C 43/18, B29C 43/28, B29C 45/14, B29C 47/02; for further classification of forming layered products, seeB32B; printing, copying B41; conveying articles or workpieces through baths of liquid B65G, e.g., B65G 49/02; handling webs or filaments in general B65H;

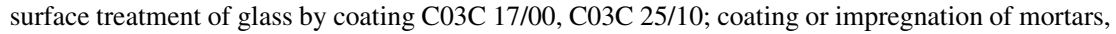
concrete, stone or ceramics C04B 41/45, C04B 41/61, C04B 41/81; paints, varnishes, lacquers C09D; enamelling of metals, applying a vitreous layer to metals, chemical cleaning or de-greasing of metallic objects $\mathrm{C} 23$; electroplating $\mathrm{C} 25 \mathrm{D}$; treating of textile materials by liquids, gases or vapours D06B; laundering D06F; treating roads E01C; apparatus or processes for the preparation or treatment of photosensitive materials G03; apparatus or processes, restricted to a purpose fully provided for in a single other class, see the relevant class covering the purpose)

b06 GENERATING OR TRANSMITTING MECHANICAL VIBRATIONS IN GENERAL

b07 SEPARATING SOLIDS FROM SOLIDS; SORTING (separation in general B01D; wet separating processes, sorting by processes using fluent material in the same way as liquid B03; using liquids B03B, B03D; sorting by magnetic or electrostatic separation of solid materials from solid materials or fluids, separation by high voltage electric fields B03C; centrifuges or vortex apparatus for carrying out physical processes B04; sorting peculiar to particular materials or articles and provided for in other classes, see the relevant classes)

b08 CLEANING

b09 DISPOSAL OF SOLID WASTE; RECLAMATION OF CONTAMINATED SOIL (treatment of waste water, sewage or sludge C02F; treating radioactively contaminated solids G21F 9/28) [3, 6]

MECHANICAL METAL-WORKING WITHOUT ESSENTIALLY REMOVING MATERIAL;

PUNCHING METAL (casting, powder metallurgy B22; shearing B23D; working of metal by the action of a high concentration of electric current B23H; soldering, welding, flame-cutting B23 K; other working of metal $\mathrm{B} 23 \mathrm{P}$; punching sheet material in general $\mathrm{B} 26 \mathrm{~F}$; processes for changing of physical properties of metals C21D, C22F; electroforming C25D 1/00)

b22 CASTING; POWDER METALLURGY

b24 GRINDING; POLISHING

b25 HAND TOOLS; PORTABLE POWER-DRIVEN TOOLS; HANDLES FOR HAND IMPLEMENTS; WORKSHOP EQUIPMENT; MANIPULATORS

b26 HAND CUTTING TOOLS; CUTTING; SEVERING

b27 WORKING OR PRESERVING WOOD OR SIMILAR MATERIAL; NAILING OR STAPLING MACHINES IN GENERAL

b29 WORKING OF PLASTICS; WORKING OF SUBSTANCES IN A PLASTIC STATE IN GENERAL

b30 PRESSES

b31 MAKING PAPER ARTICLES; WORKING PAPER (making layered products not composed wholly of paper or cardboard B32B; handling thin material, e.g., sheets, webs, B65H)

b32 LAYERED PRODUCTS

b41 PRINTING; LINING MACHINES; TYPEWRITERS; STAMPS (reproduction or duplication of pictures or patterns by scanning and converting into electrical signals H04 N) [4]

b42 BOOKBINDING; ALBUMS; FILES; SPECIAL PRINTED MATTER

b43 WRITING OR DRAWING IMPLEMENTS; BUREAU ACCESSORIES

b44 DECORATIVE ARTS

b60 VEHICLES IN GENERAL

b62 LAND VEHICLES FOR TRAVELLING OTHERWISE THAN ON RAILS 
Table 11 continued

\section{Class Description}

b63 SHIPS OR OTHER WATERBORNE VESSELS; RELATED EQUIPMENT

b64 AIRCRAFT; AVIATION; COSMONAUTICS

b65 CONVEYING; PACKING; STORING; HANDLING THIN OR FILAMENTARY MATERIAL

b66 HOISTING; LIFTING; HAULING

b67 OPENING OR CLOSING BOTTLES, JARS OR SIMILAR CONTAINERS; LIQUID HANDLING (nozzles in general B05B; packaging liquids B65B, e.g., B65B 3/00; pumps in general F04; siphons F04F 10/00; valves F16 K; handling liquefied gases F17C)

b81 MICRO-STRUCTURAL TECHNOLOGY (NANO-TECHNOLOGY)

b82 NANO-TECHNOLOGY

c01 INORGANIC CHEMISTRY (processing powders of inorganic compounds preparatory to the manufacturing of ceramic products C04B 35/00; fermentation or enzyme-using processes for the preparation of elements or inorganic compounds except carbon dioxide C12P 3/00; obtaining metal compounds from mixtures, e.g., ores, which are intermediate compounds in a metallurgical process for obtaining a free metal $\mathrm{C} 21 \mathrm{~B}, \mathrm{C} 22 \mathrm{~B}$; production of non-metallic elements or inorganic compounds by electrolysis or electrophoresis $\mathrm{C} 25 \mathrm{~B}$ )

c02 TREATMENT OF WATER, WASTE WATER, SEWAGE, OR SLUDGE (settling tanks, filtering, e.g., sand filters or screening devices, B01D)

c03 GLASS; MINERAL OR SLAG WOOL

c04 CEMENTS; CONCRETE; ARTIFICIAL STONE; CERAMICS; REFRACTORIES (alloys based on refractory metals $\mathrm{C} 22 \mathrm{C}$ )

c05 FERTILISERS; MANUFACTURE THEREOF (processes or devices for granulating materials, in general B01 J 2/00; soil-conditioning or soil-stabilising materials C09K 17/00) [4]

c06 EXPLOSIVES; MATCHES

c07 ORGANIC CHEMISTRY

c08 ORGANIC MACROMOLECULAR COMPOUNDS; THEIR PREPARATION OR CHEMICAL WORKING-UP; COMPOSITIONS BASED THEREON (manufacture or treatment of artificial threads, fibres, bristles or ribbons D01)

c09 DYES; PAINTS; POLISHES; NATURAL RESINS; ADHESIVES; COMPOSITIONS NOT OTHERWISE PROVIDED FOR; APPLICATIONS OF MATERIALS NOT OTHERWISE PROVIDED FOR

c10 PETROLEUM, GAS OR COKE INDUSTRIES; TECHNICAL GASES CONTAINING CARBON MONOXIDE; FUELS; LUBRICANTS; PEAT

c11 ANIMAL OR VEGETABLE OILS, FATS, FATTY SUBSTANCES OR WAXES; FATTY ACIDS THEREFROM; DETERGENTS; CANDLES (edible oil or fat compositions A23)

c12 BIOCHEMISTRY; BEER; SPIRITS; WINE; VINEGAR; MICROBIOLOGY; ENZYMOLOGY; MUTATION OR GENETIC ENGINEERING

c13 SUGAR INDUSTRY (polysaccharides, e.g., starch, derivatives thereof C08B; malt C12C) [4]

c14 SKINS; HIDES; PELTS; LEATHER

c21 METALLURGY OF IRON

c22 METALLURGY (of iron C21); FERROUS OR NON-FERROUS ALLOYS; TREATMENT OF ALLOYS OR NON-FERROUS METALS

c23 METALLURGY (of iron C21); FERROUS OR NON-FERROUS ALLOYS; TREATMENT OF ALLOYS OR NON-FERROUS METALS (general methods or devices for heat treatment of ferrous or non-ferrous metals or alloys C21D; production of metals by electrolysis or electrophoresis $\mathrm{C} 25$ ) 
Table 11 continued

\section{Class Description}

c25 ELECTROLYTIC OR ELECTROPHORETIC PROCESSES; APPARATUS THEREFOR

(electrodialysis, electro-osmosis, separation of liquids by electricity B01D; working of metal by the action of a high concentration of electric current $\mathrm{B} 23 \mathrm{H}$; treatment of water, waste water or sewage by electrochemical methods $\mathrm{C} 02 \mathrm{~F} 1 / 46$; surface treatment of metallic material or coating involving at least one process provided for in class $\mathrm{C} 23$ and at least one process covered by this class $\mathrm{C} 23 \mathrm{C}$ 28/00, C23F 17/00; anodic or cathodic protection C23F; single-crystal growth C30B; metallising textiles D06M 11/83; decorating textiles by locally metallising D06Q 1/04; electrochemical methods of analysis G01N; electrochemical measuring, indicating or recording devices G01R; electrolytic circuit elements, e.g., capacitors, H01G; electrochemical current or voltage generators H01M) [4]

c30 CRYSTAL GROWTH (separation by crystallisation in general B01D 9/00)

c40 COMBINATORIAL TECHNOLOGY [2006.01]

d01 NATURAL OR ARTIFICIAL THREADS OR FIBRES; SPINNING (metal threads B21; fibres or filaments of softened glass, minerals, or slag C03B 37/00; yarns D02)

d02 YARNS; MECHANICAL FINISHING OF YARNS OR ROPES; WARPING OR BEAMING

d03 WEAVING

d04 BRAIDING; LACE-MAKING; KNITTING; TRIMMINGS; NON-WOVEN FABRICS

d05 CONTROLLING; REGULATING

d06 TREATMENT OF TEXTILES OR THE LIKE; LAUNDERING; FLEXIBLE MATERIALS NOT OTHERWISE PROVIDED FOR

d07 ROPES; CABLES OTHER THAN ELECTRIC

d21 PAPER-MAKING; PRODUCTION OF CELLULOSE

e01 CONSTRUCTION OF ROADS, RAILWAYS, OR BRIDGES (of tunnels E21D)

e03 WATER SUPPLY; SEWERAGE

e04 BUILDING (layered materials, layered products in general)

e05 LOCKS; KEYS; WINDOW OR DOOR FITTINGS; SAFES

f01 MACHINES OR ENGINES IN GENERAL (combustion engines F02; machines for liquids F03, F04); ENGINE PLANTS IN GENERAL; STEAM ENGINES

f02 COMBUSTION ENGINES (cyclically operating valves therefor, lubricating, exhausting, or silencing engines F01); HOT-GAS OR COMBUSTION-PRODUCT ENGINE PLANTS

f03 MACHINES OR ENGINES FOR LIQUIDS (for liquids and elastic fluids F01; positive-displacement machines for liquids F04); WIND, SPRING, OR WEIGHT MOTORS; PRODUCING MECHANICAL POWER OR A REACTIVE PROPULSIVE THRUST, NOT OTHERWISE PROVIDED FOR

f15 FLUID-PRESSURE ACTUATORS; HYDRAULICS OR PNEUMATICS IN GENERAL

f16 ENGINEERING ELEMENTS OR UNITS; GENERAL MEASURES FOR PRODUCING AND MAINTAINING EFFECTIVE FUNCTIONING OF MACHINES OR INSTALLATIONS; THERMAL INSULATION IN GENERAL

f17 STORING OR DISTRIBUTING GASES OR LIQUIDS (water supply E03B)

f21 LIGHTING (electric aspects or elements, see section H, e.g., electric light sources H01J, H01K, H05B)

f22 STEAM GENERATION (chemical or physical apparatus for generating gases B01 J; chemical generation of gas, e.g., under pressure, Section C; removal of combustion products or residues, e.g., cleaning of the combustion contaminated surfaces of tubes of boilers, F23J; generating combustion products of high pressure or high velocity F23R; water heaters not for steam generation F24H, F28; cleaning of internal or external surfaces of heat-transfer conduits, e.g., water tubes of boilers, F28G) 
Table 11 continued

\section{Class Description}

f24 HEATING; RANGES; VENTILATING (protecting plants by heating in gardens, orchards, or forests A01G 13/06; baking ovens and apparatus A21B; cooking devices other than ranges A47J; forging B21J, B21K; specially adapted for vehicles, see the relevant subclasses of classes B60-B64; combustion apparatus in general F23; drying F26B; ovens in general F27; electric heating elements or arrangements $\mathrm{H} 05 \mathrm{~B}$ )

f26 Drying

f28 HEAT EXCHANGE IN GENERAL (heat-transfer, heat-exchange or heat-storage materials C09K $5 / 00$; arrangement or mounting of heat-exchangers in air-conditioning, air-humidification or ventilation F24F 13/30)

g01 MEASURING (counting G06M); TESTING

g02 OPTICS (making optical elements or apparatus B24B, B29D 11/00, C03, or other appropriate subclasses or classes; materials per se, see the relevant places, e.g., C03B, C03C)

g03 PHOTOGRAPHY; CINEMATOGRAPHY; ANALOGOUS TECHNIQUES USING WAVES OTHER THAN OPTICAL WAVES; ELECTROGRAPHY; HOLOGRAPHY

g04 HOROLOGY

g05 CONTROLLING; REGULATING

g06 COMPUTING; CALCULATING; COUNTING (score computers for games A63B 71/06, A63D 15/20, A63F 1/18; combinations of writing implements with computing devices B43K 29/08)

\section{g07 CHECKING-DEVICES}

g08 SIGNALLING (indicating or display devices per se G09F; transmission of pictures H04N)

g09 EDUCATING; CRYPTOGRAPHY; DISPLAY; ADVERTISING; SEALS

g10 MUSICAL INSTRUMENTS; ACOUSTICS

g11 INFORMATION STORAGE

g21 NUCLEAR PHYSICS; NUCLEAR ENGINEERING

h01 BASIC ELECTRIC ELEMENTS

h02 GENERATION, CONVERSION, OR DISTRIBUTION OF ELECTRIC POWER

h03 BASIC ELECTRONIC CIRCUITRY

h04 ELECTRIC COMMUNICATION TECHNIQUE

h05 ELECTRIC TECHNIQUES NOT OTHERWISE PROVIDED FOR

\section{References}

Arundel, A., van de Paal, G., \& Soete, L. (1995). Innovation strategies of Europe's largest industrial firms, results of the PACE survey for information sources, public research, protection of innovations and government programmes, Final Report, MERIT, June.

Arvanitis, S., Kubli, U., Sydow, N., \& Woerter, M. (2007). Knowledge and technology transfer (KTT) activities between universities and firms in Switzerland: The main facts. The Icfai Journal of Knowledge Management, V(6), 17-75, November.

Arvanitis, S., Sydow, N., \& Woerter, M. (2008). Is there any impact of university-industry knowledge transfer on the performance of private enterprises? An empirical analysis based on Swiss firm data. Review of Industrial Organization, 32, 77-94.

Audretsch, D. B., \& Stephan, P. E. (1996). Company-scientist locational links: The case of biotechnology. The American Economic Review, 86(3), 641-652.

Barney, J. (1991). Firm resources and sustained competitive advantage. Journal of Management, 17, 99-120.

Barney, J., Wright, M., \& Ketchen, D. J. (2001). The resource-based view of the firm: Ten years after 1991. Journal of Management, 27, 625-641. 
Battisti, G., Hollenstein, H., Stoneman, P., \& Woerter, M. (2007). Inter and intra firm diffusion of ICT in the United Kingdom (UK) and Switzerland $(\mathrm{CH})$ : An internationally comparative study based on firmlevel data. Economics of Innovation and New Technology, 16(8), 669-687.

Beise, M., Licht, G., \& Spielkamp, A. (1995). Technologietransfer an kleine und mittlere UnternehmenAnalysen und Perspektiven für Baden-Württemberg, Schriftenreihe des ZEW, Nomos Verlagsgesellschaft, Baden-Baden.

Blume, L., \& Fromm, O. (2000). Wissenstransfer zwischen Universitäten und regionale Wirtschaft: Eine empirische Untersuchung am Beispiel der Universität Gesamthochschule Kassel. Vierteljahreshefte zur Wirtschaftsforschung, 69(1), 109-123.

Boschma, R. A. (2005). Proximity and innovation: A critical assessment. Regional Studies, 39(1), 61-74.

Boschma, R. A., \& ter Wal, A. L. J. (2007). Knowledge networks and innovative performance in an industrial district: The case of a footwear district in the South of Italy. Industry and Innovation, 14(2), 177-199.

Breschi, S., \& Lissoni, F. (2006). Mobility of inventors and the geography of knowledge spillovers. New evidence on US data. CESPRI Working Paper 184.

Bresnahan, T. F., Brynjolfsson, E., \& Hitt, L. M. (2002). Information technology, workplace organisation, and the demand for skilled labor: Firm-level evidence. Quarterly Journal of Economics, 117, 339-376.

Broekel, T. (2007). A concordance between industries and technologies matching the technological fields of the patentatlas to the German industry classification. Jena Economic Research Papers (2007-041), pp. 1-21.

Cantner, U., \& Meder, A. (2007). Technological proximity and the choice of cooperation partner. Journal of Economic Interaction and Coordination, 2, 45-65. doi:10.1007/s11403-007-0018-y.

Cohen, W., \& Levinthal, D. (1989). Innovation and learning: The two faces of R\&D. Economic Journal, 99(397), 569-596.

Dosi, G. (1982). Technological paradigms and technological trajectories. Research Policy, 11, 147-162.

Dosi, G. (1988). Sources, procedures, and microeconomic effects of innovation. Journal of Economic Literature, 26, 1120-1171 (September).

Geisler, E., \& Rubinstein, A. H. (1989). University-industry relations: A review of major issues. In A. N. Link \& G. Tassey (Eds.), Co-operative research and development: The industry-universitygovernment relationship. London: Kluwer.

Gibbons, M., Limoges, C., Nowotny, H., Schwartzman, S., Scott, P., \& Trow, M. (1994). The new production of knowledge. London, Thousand Oaks, New Delhi: Sage Publications.

Greenlee, P., \& Cassiman, B. (1999). Product market objectives and the formation of research joint ventures. Managerial and Decision Economics, 20, 115-130.

Griliches, Z. (1990). Patent statistics as economic indicators: A survey. Journal of Economic Literature, 28(4), 1661-1707.

Hall, B. H. (2001). University-industry research partnerships and intellectual property. NSF-CISTP Workshop, October.

Hall, B. H. (2004) University-industry research partnerships in the United States. Kansai Conference Paper, February.

Hempell, T., van Leeuwen, G., \& van der Wiel, H. (2004). ICT, innovation and business performance in services: Evidence for Germany and the Netherlands. In OECD (Ed.), The economic impact of ICT. Measurement, evidence and implications (pp. 131-152). Paris: OECD.

Hollenstein, H. (2004). Determinants of the adoption of information and communication technologies (ICT) - an empirical analysis based on firm-level data for the Swiss business sector. Structural Change and Economic Dynamics, 15, 315-342.

Izushi, H. (2002). Impact of the length of relationships upon the use of research institutes by SMEs. Research Policy, 32, 1-18.

Jaffe, A. B. (1986). Technological opportunity and spillovers of R\&D: Evidence from firms' patents, profits, and market values. The American Economic Review, 76, 984-1001.

Kahn, M. E. (2005). The death toll from natural disasters: The role of income, geography, and institutions. Review of Economics and Statistics, 87, 271-284.

Kaufmann, A., \& Tödling, F. (2001). Science-research interaction in the process of innovation: The importance of boundary-crossing between systems. Research Policy, 30, 791-804.

Kor, Y. Y., \& Mahoney, J. T. (2004). Edith Penrose's (1959) contributions to the resource-based view of strategic management. Journal of Management Studies, 41(1), 183-191.

Lang, J. (2008). Forschungs—und Entwicklungstätigkeiten von Unternehmen und Hochschulen im In-und Ausland. Zürich: Arbeitsbericht.

Laursen, K., \& Salter, A. (2004). Searching high and low: What types of firms use universities as a source of innovation? Research Policy, 33, 1201-1215. 
Lee, Y. S. (2000). The sustainability of university-industry research collaboration: An empirical assessment. Journal of Technology Transfer, 25, 111-133.

Leibenstein, H. (1989). Organizational or frictional equilibria, X-efficiency, and the rate of innovation. In K. Burton (Ed.), The collected essays of Harvey Leibenstein, volume 2. X-efficiency and micro-micro theory. Aldershot: Edward Elgar Publishing Limited.

Lessmann, G., \& Rosner, U. (2004). Aufschwung Ost durch Öffentliche Wissenschaftseinrichtungen-can research institutions make the East German economy prosper? Working Paper Nr. 04004-FEMM (Faculty of Economics and Management Magdeburg), Magdeburg, April.

Malerba, F. (2007). Innovation and the dynamics and evolution of industries: Progress and challenges. International Journal of Industrial Organization, 25, 675-699.

March, J. (1991). Exploration and exploitation in organizational learning. Organization Science, 2, 71-87.

Nelson, R. R., \& Winter, S. G. (1982). An evolutionary theory of economic change. Cambridge: Belknap Press of Harvard University Press.

Nooteboom, B., Van Haverbeke, W., Duysters, G., Gilsing, V., \& van den Oord, Ad. (2007). Optimal cognitive distance and absorptive capacity. Research Policy, 36, 1016-1034.

OECD. (2002). Benchmarking industry-science relationships. Paris: OECD.

Onida, F., \& Malerba, F. (1989). R\&D co-operation between industry, universities and research organizations in Europe, background report. Technovation 9, 131-193.

Pavitt, K. (1984). Sectoral patterns of technical change: Towards a taxonomy and a theory. Research Policy, $13,343-374$.

Penrose, E. (1995). The theory of the growth of the firm (3rd ed.). Oxford, New York: Oxford University Press.

Powell, W. W., Koput, K. W., \& Smith-Doerr, L. (1996). Interorganizational collaboration and the locus of innovation: Networks of learning in biotechnology. Administrative Science Quarterly, 41(1), 116-145.

Salter, A., D'Este, P., Martin, B., Geuna, A., Scott, A., Pavitt, K., et al. (2000). Talent, not technology: Publicly funded research and innovation in the UK, SPRU (Science and Technology Policy Research). Brighton: University of Sussex.

Santoro, M. D., \& Chakrabarti, A. K. (2002). Firm size and technology centrality in industry-university interactions. Research Policy, 31, 1163-1180.

Santoro, M. D., \& Gopalakrishnan, S. (2001). Relationship dynamics between university research centers and industrial firms: Their impact on technology transfer activities. Journal of Technology Transfer, $26,163-171$.

Schartinger, D., Gassler, H., \& Schibany, A. (2000). Benchmarking industry-science relations, National Report-Austria, Final Report, OEFZS-S-0099, Oesterreichisches Forschungszentrum Seibersdorf, Seibersdorf.

Schartinger, D., Schibany, A., \& Gassler, H. (2001). Interactive relations between universities and firms: Empirical evidence for Austria. Journal of Technology Transfer, 26, 255-268.

Schibany, A., Jörg, L., \& Polt, W. (1999). Towards realistic expectations. The science system as a contributor to industrial innovation, Tip-report, Vienna.

Schmidt, T. (2008). Absorptive capacity—one size fits all? A firm-level analysis of absorptive capacity for different kinds of knowledge. Managerial and Decision Economics, Forthcoming 2009.

Schmoch, U. (2003). Hochschulforschung und Industrieforschung, Perspektiven und Interaktion, Campus Forschung Band 858, Campus Verlag, Frankfurt, New York.

Schmoch, U., Laville, F., Patel, P., \& Frietsch, R. (2003). Linking technology areas to industrial sectors. Final Report to the European Commission, DG Research, Karlsruhe, Paris, Brighton.

Shapiro, C., \& Willig, R. (1990). On the antitrust treatment of production joint ventures. Journal of Economic Perspectives, 4, 113-130.

Simon, H. A. (1956). Rational choice and the structure of the environment. In M. Egidi \& R. Marris (1992) (Eds.), Economics, bounded rationality and the cognitive revolution, Herbert Simon. Edward Elgar Publishing Limited, Aldershot, Brookfield.

Stephan, P. E. (1996). The economics of science. Journal of Economic Literature, 34(3), 1194-1235.

Sumell, A. J, Stephan, P. E., \& Adams, J. D. (2009). Capturing knowledge: The decision of new PhDs working in industry. In R. B. Freeman \& D. L. Goroff (Eds.), Science and engineering careers in the United States: An analysis of markets and employment. Chicago: University of Chicago Press, pp. 257-287.

Teece, D. J., Pisano, G., \& Shuen, A. (1997). Dynamic capabilities and strategic management. Strategic Management Journal, 18(7), 507-533. 
Verspagen, B., van Moergastel, T., \& Slabbers, M. (1994). MERIT concordance table: IPC-ISIC (rev. 2). MERIT Research Memorandum 2/94-004, Maastricht.

Wernerfelt, B. (1984). A resource-based view of the firm. Strategic Management Journal, 5, 171-180.

Wooldridge, J. M. (2003). Introductory econometrics-a modern approach. Mason OH: Thomson SouthWestern. 